\title{
A meta-analysis on the risk factors adjusted association between cardiovascular disease and COVID-19 severity
}

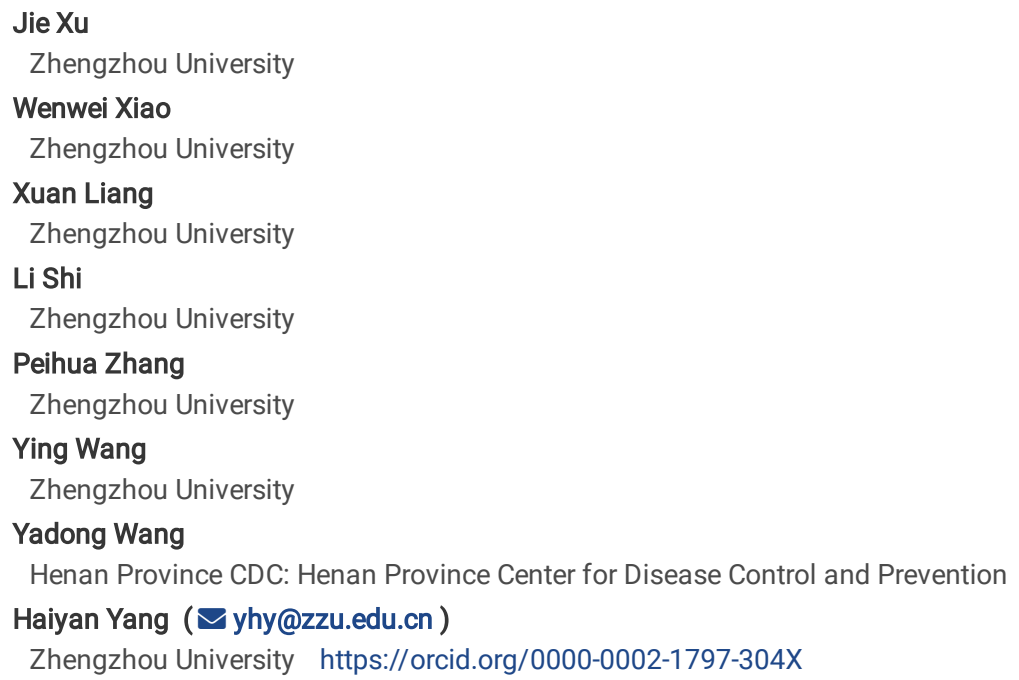

Version of Record: A version of this preprint was published at BMC Public Health on August 11th, 2021. See the published version at https://doi.org/10.1186/s12889-021-11051-w. 


\section{Abstract \\ Background}

Cardiovascular disease (CVD), one of the most common comorbidities of coronavirus disease 2019 (COVID-19), has been suspected to be associated with adverse outcomes in COVID-19 patients, but their correlation remains controversial.

\section{Method}

This is a quantitative meta-analysis on the basis of adjusted effect estimates. PubMed, Web of Science, MedRxiv, Scopus, Elsevier ScienceDirect, Cochrane Library and EMBASE were searched comprehensively to obtain a complete data source up to January 7, 2021. Pooled effects (hazard ratio (HR), odds ratio (OR)) and the $95 \%$ confidence intervals (Cls) were estimated to evaluate the risk of the adverse outcomes in COVID-19 patients with CVD. Heterogeneity was assessed by Cochran's Q-statistic, I'test, and meta-regression. In addition, we also provided the prediction interval, which was helpful for assessing whether the variation across studies was clinically significant. The robustness of the results was evaluated by sensitivity analysis. Publication bias was assessed by Begg's test, Egger's test, and trim-and-fill method.

\section{Result}

Our results revealed that COVID-19 patients with pre-existing CVD tended more to adverse outcomes on the basis of 203 eligible studies with $24,033,838$ cases (pooled ORs $=1.41,95 \%$ Cls: $1.32-1.51$, prediction interval: 0.84-2.39; pooled HRs $=1.34,95 \%$ Cls: $1.23-1.46$, prediction interval: $0.82-2.21$ ). Further subgroup analyses stratified by age, the proportion of male, study design, disease types, sample size, region and disease outcomes also showed that preexisting CVD was significantly associated with adverse outcomes among COVID-19 patients.

\section{Conclusion}

Our findings demonstrated that pre-existing CVD was an independent risk factor associated with adverse outcomes among COVID-19 patients.

\section{Background}

Since December 2019, the severe acute respiratory syndrome coronavirus 2 (SARS-CoV-2) has caused a global outbreak of COVID-19. Currently, the pandemic has affected more than 127,319,002 people in more than 200 countries and killed more than 2,785,838 people

(https://www.who.int/emergencies/diseases/novel-coronavirus-2019). Previous studies have reported that several pre-existing medical conditions, such as hypertension, diabetes and so on, might accelerate disease progression of coronavirus disease 2019 (COVID-19) [1-3]. Cardiovascular disease (CVD), one of the most common comorbidities of COVID-19, has been observed to be associated with adverse outcomes among COVID-19 patients by Li et al. in a metaanalysis study [4]. Nevertheless, it is worth noting that the results of Li et al.'s study were based on the unadjusted effect estimates [4]. It is reported that age, sex, and co-existing diseases are known to affect the outcomes of COVID-19 patients [5-7], which may modulate the association between CVD and adverse outcomes in COVID-19 patients. Moreover, Zhou et al. observed that coronary heart disease (CHD), one of CVD, was strongly correlated with an increased risk of in-hospital mortality among COVID-19 patients in univariable analysis (odds ratio (OR) = 21.4, 95\% confidence interval (CI): $4.64-98.76$ ), but no significant correlation was observed in multivariable analysis $(\mathrm{OR}=2.14,95 \% \mathrm{Cl}: 0.26-17.79)$ [8]. The similar results were also observed by Robilotti et al. [9] and Louapre et al. [10]. Therefore, it is necessary to clarify whether pre-existing CVD was an independent risk factor associated with adverse outcomes in COVID-19 patients. In this study, we performed a quantitative meta-analysis on the basis of adjusted effect estimates.

\section{Method}

This is a quantitative meta-analysis on the basis of adjusted effect estimates. Admittedly, our study was not registered, but our meta-analysis was made in strict accordance with the process of systematic evaluation (Fig.1). Moreover, our study is less likely to be biased by artificial bias because this study was carried out rigorously in accordance with the Preferred Reporting Items for Systematic Reviews and Meta-analysis (PRISMA) guidelines (Online supplemental Table A1) [11].

\section{Literature search strategy}

The databases of PubMed, Web of Science, MedRxiv, Scopus, Elsevier ScienceDirect, Cochrane Library and Embase were searched to obtain a complete data source up to January 7, 2021. The search strategies were as follows: ("COVID-19" OR "coronavirus disease 2019" OR "SARS-CoV-2" OR "2019-nCoV") AND ("cardiovascular disease" OR "coronary heart disease" OR "cardiac disease" OR "heart disease" OR "heart failure" OR "coronary artery disease") AND ("outcome" "severe" OR "critical" OR "severity" OR "fatality" OR "mortality" OR "death" OR "adverse outcome" OR "poor outcome" OR "clinical characteristics"). All the terms matched the MesH browser. Beyond that, the relevant references of preceding studies were also taken into account.

\section{Eligibility criteria}

The criteria for including studies were: (1) Subjects should be laboratory-confirmed COVID-19 patients; (2) Studies should report the correlation between CVD and COVID-19 patients and the data are available; (3) Studies should be published in English; (4) Studies should include the multivariate analysis. The studies with the largest sample size were selected for inclusion when studies were conducted in the same hospital and the overlapping period. There was no 
restriction for region of study. The exclusion criteria included case reports, review papers, comments, errata, repeated studies, studies only reporting the characteristics of COVID-19 patients with CVD, and studies without available full text.

\section{Data extraction and quality assessment}

Data were extracted independently by two investigators (J.X. and W.X.), including the following information: the first author, source of data, country, date of data collection, number of patients, mean/median age, the percent of male, study design, the percent of COVID-19 patients with CVD, adjusted effect estimates ( $\mathrm{HR}$ or $\mathrm{OR}$ ) and adjusted risk factors. When both $\mathrm{OR}$ and HR existed in the same article, it was preferred to include HR because cox regression took time into account. Two researchers negotiated to resolve it in case of any issues not covered by the criteria and Y.W. acted as arbiter. The quality of the included studies was evaluated by investigators according to the Newcastle-Ottawa Scale [12]. High-quality studies referred to studies with a score above 7.

\section{Data synthesis}

The major information such as study design and effect estimates were directly extracted from original articles. The research type of some articles was not clear and some articles provided both OR and HR. Besides, the calculation methods of HR and OR are different. The calculation of HR takes into account the concept of time, and OR is the approximate value of risk ratio. Therefore, pooled HR, OR and 95\% Cls were separately calculated to address the risk of adverse outcomes in COVID-19 patients with a history of CVD. Heterogeneity was assessed by Cochran's Q-statistic and $\mathrm{I}^{2}$ test, if no significant heterogeneity was observed $\left(I^{2} \leq 50 \%, P>0.1\right)$, a fixed-effects model was adopted; otherwise, a random-effects model was applied [13]. In addition, we also provided the prediction interval, which was helpful for assessing whether the variation across studies was clinically significant $[14,15]$. The robustness of the results was evaluated by sensitivity analysis which omitted one study at a time. Publication bias was assessed by Begg's test [16], Egger's test [17] and trim-and-fill method [18]. Subgroup analysis and meta-regression were conducted to determine the source of heterogeneity. Data analyses were conducted using Stata, version 12.0 (meta-program) and $\mathrm{R}$, version 3.6.1 (netmeta package). A two-tailed P-value $<0.05$ was regarded as significant.

\section{Results}

The flow chart of selection process is shown in Fig. 1. 5,025 records were retrieved after removing 23,826 duplicates, of which 245 studies were full-text assessed. Eventually, a total of 203 eligible studies with 24,033,838 patients were enrolled in our meta-analysis [2, 3, 8, 9, 19-218]. 81 studies originated from Europe, 54 studies came from North America, 61 from Asia, 2 from Australia, and the remained 5 were not just from one country. Among these studies, cardiac disease was mentioned in 63 studies, HF was involved in 35 studies, and CAD was involved in 35 studies. Adjusted HR was reported in 65 studies and adjusted OR was reported in 138 studies. The main characteristics of the selected studies are summarized in Table 1.

Totally, our results revealed that COVID-19 patients who suffered from CVD tended more to adverse outcomes (pooled ORs $=1.41,95 \%$ Cls: $1.32-1.51$, prediction interval: 0.84-2.39; pooled HRs $=1.34,95 \% \mathrm{Cls}$ : 1.23-1.46, prediction interval: 0.82-2.21 Fig. 2). Subgroup analysis by sample size showed consistent results (pooled HRs $=1.16,95 \%$ Cls: 1.03-1.32, prediction interval: 0.66-2.04; pooled ORs $=1.41,95 \%$ Cls: $1.32-1.51$, prediction interval: $0.84-2.39$ for sample size >= 1000; pooled HRs = 1.63, 95\% Cls: 1.41-1.88, prediction interval: 0.86-3.10; pooled ORs: 1.57, 95\% Cls: 1.40-1.77, prediction interval: 0.84-2.95 for sample size < 1000; Table 2 and Fig. A1). The positive association between pre-existing CVD and adverse outcomes in COVID-19 patients was also observed in subgroup analysis by disease types (Table 2 and Fig. A2): cardiac disease (pooled HRs = 1.40, 95\% Cls: 1.17-1.69, prediction interval: 0.68-2.90; pooled ORs $=1.43,95 \%$ Cls: $1.25-1.64$, prediction interval: 0.80-2.55), HF (pooled HRs $=1.23,95 \%$ Cls: $1.05-1.44$, prediction interval: $0.63-2.39 ;$ pooled ORs = 1.46, 95\% Cls: 1.31-1.62, prediction interval: 1.01-2.10), and CAD (pooled HRs $=1.48,95 \%$ Cls: 1.14-1.93, prediction interval: $0.67-3.29 ;$ pooled ORs $=1.17,95 \%$ Cls:1.02-1.35, prediction interval: 0.75-1.83). In addition, subgroup analyses stratified by age, the proportion of male, region, disease outcomes and study design supported the above positive associations (Table 2 and Fig. A3-7). Sensitivity analysis indicated that our result was robust (Fig.3A and B). There was no publication bias was detected by Begg's test (OR: $P=0.233$, HR: $P=0.054$; Fig. $4 A$ and $B$, while significant publication bias was found by Egger's test (OR: $P$ $=0.000, \mathrm{HR}: \mathrm{P}=0.000$; Fig. $4 \mathrm{C}$ and $\mathrm{D}$ ). Therefore, the trim-and-fill method was adopted for further analysis. The results for HR showed that with the addition of 21 more studies, the results of the meta-analysis would be more robust but not reversed (pooled HRs $=1.11,95 \%$ Cls: 1.01-1.14, fixed-effects model; pooled HRs $=1.16,95 \%$ Cls: 1.06-1.26, random-effects model), and the OR results (pooled ORs: 1.18, 95\% Cls: 1.16-1.20, fixed-effects model; pooled ORs: 1.21, 95\% Cls: 1.12-1.30, random-effects model) showed that the results would be equally robust after adding 29 studies. However, there was high heterogeneity in our study. To find sources of heterogeneity, we conducted a meta-regression. However, adjustments for multivariate regression coefficients for sample size, age, proportion of male, study design, region, disease, outcomes were not statistically significant (Table 2), suggesting that these were not sources of heterogeneity identified.

\section{Discussion}

Many countries have been hit by the pandemic caused by SARS-CoV-2, numerous people lost their lives because of this. Meanwhile, health systems in every country were under so unprecedented strain that it was very important to find an effective marker to help implement bed grading management. What called for special attention was that earlier studies have shown COVID-19 patients with at least one underlying conditions, such as chronic kidney disease, HIV, diabetes and other comorbidities, have a poor disease course $[2,29,219,220]$, which means that those patients with underlying diseases should be monitored more carefully in case of disease getting worse. Furthermore, it was reported that the risk of primary respiratory syndrome severity and adverse outcomes was increased in Middle East respiratory syndrome (MERS) patients with pre-existing CVD [221]. The research by Li et al. [8] with unadjusted effect estimates showed that there was a positive association between CVD and adverse outcomes in patients with COVID-19, but the association might be confounded by other factors such as age, gender and comorbidities. Thus, we performed a quantitative meta-analysis on the basis of adjusted effect estimates to clarify whether pre-existing CVD was an independent risk factor associated with adverse outcomes in COVID-19 patients. 
Our results based on adjusted effect estimates revealed that pre-existing CVD was significantly related to adverse outcomes in COVID-19 patients on the basis of 203 eligible studies with 24,033,838 cases. The significant association between pre-existing CVD and adverse outcomes in COVID-19 patients was still existent in further subgroup analyses stratified by the proportion of male, disease types, sample size, region and disease outcomes, which suggests that our findings are relatively stable.

Similar to other meta-analyses, several limitations should be acknowledged in this present study. Firstly, data on drug and supportive treatments are not clear in the selected studies presently, thus, we could not evaluate the effects of treatments on the association between co-existing CVD and adverse outcomes in COVID-19 patients. Secondly, statistically significant results were more likely to be accepted and published than non-statistically significant results in similar studies, but in fact, the data of the meta-analysis mainly derived from the studies which have been published, which may lead to publication bias. Thirdly, the causal relationship of CVD and adverse outcomes in patients with COVID-19 cannot be confirmed on account of the inherent limitation of the observational study. Therefore, well-designed studies with larger sample sizes are needed for further verification.

\section{Conclusions}

In conclusion, our findings indicated that pre-existing CVD was an independent risk factor associated with adverse outcomes among COVID-19 patients. COVID-19 patients with a history of CVD might need more attention.

\section{Abbreviations}

CVD, cardiovascular disease

COVID-19, coronavirus disease 2019

$\mathrm{Cl}$, confidence interval

$\mathrm{OR}$, odds ratio

$H R$, hazard ratio

$\mathrm{CHD}$, coronary heart disease

CAD, coronary artery disease

HIV, human immunodeficiency virus

MesH, Medical Subject Headings

$H F$, heart failure

PRISMA, Preferred Reporting Items for Systematic Reviews and Meta-analysis

\section{Declarations}

\section{Ethics approval and consent to participate}

Not required.

\section{Consent for Publication}

Not applicable

\section{Availability of data and material}

All data relevant to the study are included in the article or uploaded as supplementary information.

\section{Competing interests}

The authors declare not any potential conflict of interest.

\section{Funding}

This study was supported by a grant from the National Natural Science Foundation of China (No. 81973105). The funder had no role in the study design, data collection and analysis, decision to publish, or preparation of the manuscript.

\section{Authors' Information}

Department of Epidemiology, School of Public Health, Zhengzhou University, Zhengzhou 450001, China

Jie Xu, Wenwei Xiao, Xuan Liang, Li Shi, Peihua Zhang, Ying Wang, Haiyan Yang 
Department of Toxicology, Henan Center for Disease Control and Prevention, Zhengzhou 450016, China

Yadong Wang

Author contributions

H.Y. and Y.W. designed the study; J.X., W.X., X.L. and P.Z. searched literature and extracted the data; J.X., L.S. and Y.W. contributed to the statistical analyses and interpretation; J.X. drafted the manuscript. All the authors have read and approved the final manuscript.

Acknowledgements

We would like to thank Jian Wu, Yang Li and Hongjie Hou (All are from Department of Epidemiology, School of Public Health, Zhengzhou University) for their kind help in searching articles and collecting data, and valuable suggestions for data analysis.

\section{References}

1. Liang X, Shi L, Wang Y, Xiao W, Duan G, Yang H, Wang Y: The association of hypertension with the severity and mortality of CoVID-19 patients: evidence based on adjusted effect estimates. The Journal of infection 2020:DOI: 10.1016/j.jinf.2020.1006.1060.

2. Cen Y, Chen X, Shen Y, Zhang XH, Lei Y, Xu C, Jiang WR, Xu HT, Chen Y, Zhu J et al: Risk factors for disease progression in patients with mild to moderate coronavirus disease 2019-a multi-centre observational study. Clinical microbiology and infection : the official publication of the European Society of Clinical Microbiology and Infectious Diseases 2020:DOI: 10.1016/j.cmi.2020.1005.1041.

3. Cummings MJ, Baldwin MR, Abrams D, Jacobson SD, Meyer BJ, Balough EM, Aaron JG, Claassen J, Rabbani LE, Hastie J et al: Epidemiology, clinical course, and outcomes of critically ill adults with COVID-19 in New York City: a prospective cohort study. Lancet (London, England) 2020, 395(10239):1763-1770.

4. Li X, Guan B, Su T, Liu W, Chen M, Bin Waleed K, Guan X, Gary T, Zhu Z: Impact of cardiovascular disease and cardiac injury on in-hospital mortality in patients with COVID-19: a systematic review and meta-analysis. Heart (British Cardiac Society) 2020.

5. Borghesi A, Zigliani A, Masciullo R, Golemi S, Maculotti P, Farina D, Maroldi R: Radiographic severity index in CoVID-19 pneumonia: relationship to age and sex in 783 Italian patients. La Radiologia medica 2020, 125(5):461-464.

6. Jones J, Sullivan PS, Sanchez T, Guest JL, Hall E, Luisi N, Zlotorzynska M, Wilde G, Bradley H, Siegler AJ: Similarities and differences in CoVID-19 awareness, concern, and symptoms by race and ethnicity in the United States: A cross-sectional survey. Journal of medical Internet research 2020:DOI: $10.2196 / 20001$.

7. Mustafa NM, L AS: Characterisation of COVID-19 Pandemic in Paediatric Age Group: A Systematic Review and Meta-Analysis. Journal of clinical virology : the official publication of the Pan American Society for Clinical Virology 2020, 128:104395.

8. Zhou F, Yu T, Du R, Fan G, Liu Y, Liu Z, Xiang J, Wang Y, Song B, Gu X et al: Clinical course and risk factors for mortality of adult inpatients with CoVID-19 in Wuhan, China: a retrospective cohort study. Lancet (London, England) 2020, 395(10229):1054-1062.

9. Robilotti EV, Babady NE, Mead PA, Rolling T, Perez-Johnston R, Bernardes M, Bogler Y, Caldararo M, Figueroa CJ, Glickman MS et al: Determinants of COVID-19 disease severity in patients with cancer. Nature medicine 2020:DOI: 10.1038/s41591-41020-40979-41590.

10. Louapre C, Collongues N, Stankoff B, Giannesini C, Papeix C, Bensa C, Deschamps R, Créange A, Wahab A, Pelletier J et al: Clinical Characteristics and Outcomes in Patients With Coronavirus Disease 2019 and Multiple Sclerosis. JAMA neurology 2020:DOI: 10.1001/jamaneurol.2020.2581.

11. Liberati A, Altman DG, Tetzlaff J, Mulrow C, Gøtzsche PC, loannidis JP, Clarke M, Devereaux PJ, Kleijnen J, Moher D: The PRISMA statement for reporting systematic reviews and meta-analyses of studies that evaluate healthcare interventions: explanation and elaboration. BMJ (Clinical research ed) 2009 , 339:b2700.

12. Stang A: Critical evaluation of the Newcastle-Ottawa scale for the assessment of the quality of nonrandomized studies in meta-analyses. European journal of epidemiology 2010, 25(9):603-605.

13. Greenland S: Quantitative methods in the review of epidemiologic literature. Epidemiologic reviews 1987, 9:1-30.

14. IntHout J, loannidis JP, Rovers MM, Goeman JJ: Plea for routinely presenting prediction intervals in meta-analysis. BMJ open $2016,6(7): e 010247$.

15. Borenstein M, Higgins JP, Hedges LV, Rothstein HR: Basics of meta-analysis: I(2) is not an absolute measure of heterogeneity. Research synthesis methods 2017, 8(1):5-18.

16. Begg CB, Mazumdar M: Operating characteristics of a rank correlation test for publication bias. Biometrics 1994, 50(4):1088-1101.

17. Egger M, Davey Smith G, Schneider M, Minder C: Bias in meta-analysis detected by a simple, graphical test. BMJ (Clinical research ed) 1997, 315(7109):629-634.

18. Schwarzer G, Carpenter J, Rücker G: Empirical evaluation suggests Copas selection model preferable to trim-and-fill method for selection bias in metaanalysis. Journal of clinical epidemiology 2010, 63(3):282-288.

19. Yu X, Sun X, Cui P, Pan H, Lin S, Han R, Jiang C, Fang Q, Kong D, Zhu Y et al: Epidemiological and clinical characteristics of 333 confirmed cases with coronavirus disease 2019 in Shanghai, China. Transboundary and emerging diseases 2020, 67(4):1697-1707.

20. Zhao M, Wang M, Zhang J, Gu J, Zhang P, Xu Y, Ye J, Wang Z, Ye D, Pan W et al: Comparison of clinical characteristics and outcomes of patients with coronavirus disease 2019 at different ages. Aging 2020, 12(11):10070-10086.

21. Sabri A, Davarpanah AH, Mahdavi A, Abrishami A, Khazaei M, Heydari S, Asgari R, Nekooghadam SM, Dobranowski J, Taheri MS: Novel coronavirus disease 2019: predicting prognosis with a computed tomography-based disease severity score and clinical laboratory data. Polish archives of internal

Page 5/40 
medicine 2020, 130(7-8):629-634.

22. Lala A, Johnson KW, Russak AJ, Paranjpe I, Zhao S, Solani S, Vaid A, Chaudhry F, De Freitas JK, Fayad ZA et al: Prevalence and Impact of Myocardial Injury in Patients Hospitalized with COVID-19 Infection. medRxiv : the preprint server for health sciences 2020:D0I: 10.1101/2020.1104.1120.20072702.

23. Ciceri F, Castagna A, Rovere-Querini P, De Cobelli F, Ruggeri A, Galli L, Conte C, De Lorenzo R, Poli A, Ambrosio A et al: Early predictors of clinical outcomes of COVID-19 outbreak in Milan, Italy. Clinical immunology 2020, 217:108509.

24. Barman HA, Atici A, Sahin I, Alici G, Aktas Tekin E, Baycan OF, Ozturk F, Oflar E, Tugrul S, Yavuz MB et al: Prognostic significance of cardiac injury in COVID-19 patients with and without coronary artery disease. Coronary artery disease 2020:DOI: 10.1097/MCA.0000000000000914.

25. Bravi F, Flacco ME, Carradori T, Volta CA, Cosenza G, De Togni A, Acuti Martellucci C, Parruti G, Mantovani L, Manzoli L: Predictors of severe or lethal COVID-19, including Angiotensin Converting Enzyme inhibitors and Angiotensin II Receptor Blockers, in a sample of infected Italian citizens. PloS one 2020, 15(6):e0235248.

26. Deiana G, Azara A, Dettori M, Delogu F, Vargiu G, Gessa I, Stroscio F, Tidore M, Steri G, Castiglia P: Deaths in SARS-Cov-2 Positive Patients in Italy: The Influence of Underlying Health Conditions on Lethality. International journal of environmental research and public health 2020, 17(12):DOI: 10.3390/ijerph17124450.

27. Zhang C, Qin L, Li K, Wang Q, Zhao Y, Xu B, Liang L, Dai Y, Feng Y, Sun J et al: A Novel Scoring System for Prediction of Disease Severity in COVID-19. Frontiers in cellular and infection microbiology 2020, 10:318.

28. Nie Y, Li J, Huang X, Guo W, Zhang X, Ma Y, Wang H, Qi M, Tang X, Shen X et al: Epidemiological and clinical characteristics of 671 CoVID-19 patients in Henan Province, China. International journal of epidemiology 2020:DOI: 10.1093/ije/dyaa1081.

29. Hashemi N, Viveiros K, Redd WD, Zhou JC, McCarty TR, Bazarbashi AN, Hathorn KE, Wong D, Njie C, Shen L et al: Impact of Chronic Liver Disease on Outcomes of Hospitalized Patients with COVID-19: A Multicenter United States Experience. Liver international : official journal of the International Association for the Study of the Liver 2020:DOI: 10.1111/liv.14583.

30. Lanza E, Muglia R, Bolengo I, Santonocito OG, Lisi C, Angelotti G, Morandini P, Savevski V, Politi LS, Balzarini L: Quantitative chest CT analysis in COVID19 to predict the need for oxygenation support and intubation. European radiology 2020:DOI: 10.1007/s00330-00020-07013-00332.

31. Zeng Z, Ma Y, Zeng H, Huang P, Liu W, Jiang M, Xiang X, Deng D, Liao X, Chen P et al: Simple nomogram based on initial laboratory data for predicting the probability of ICU transfer of COVID-19 patients: Multicenter retrospective study. Journal of medical virology 2020:DOI: 10.1002/jmv.26244.

32. Petrilli CM, Jones SA, Yang J, Rajagopalan H, O'Donnell LF, Chernyak Y, Tobin K, Cerfolio RJ, Francois F, Horwitz LI: Factors associated with hospitalization and critical illness among 4,103 patients with COVID-19 disease in New York City. 2020:2020.2004.2008.20057794.

33. Arshad S, Kilgore P, Chaudhry ZS, Jacobsen G, Wang DD, Huitsing K, Brar I, Alangaden GJ, Ramesh MS, McKinnon JE et al: Treatment with hydroxychloroquine, azithromycin, and combination in patients hospitalized with COVID-19. International journal of infectious diseases : IJID : official publication of the International Society for Infectious Diseases 2020, 97:396-403.

34. San Roman JA, Uribarri A, Amat-Santos IJ, Aparisi A, Catala P, Gonzalez-Juanatey JR: The presence of heart disease worsens prognosis in patients with COVID-19. Revista espanola de cardiologia 2020, 73(9):773-775.

35. Cheng B, Hu J, Zuo X, Chen J, Li X, Chen Y, Yang G, Shi X, Deng A: Predictors of progression from moderate to severe coronavirus disease 2019: a retrospective cohort. Clinical microbiology and infection : the official publication of the European Society of Clinical Microbiology and Infectious Diseases 2020:DOI: 10.1016/j.cmi.2020.1006.1033.

36. Oussalah A, Gleye S, Clerc Urmes I, Laugel E, Callet J, Barbe F, Orlowski S, Malaplate C, Aimone-Gastin I, Caillierez BM et al: Long-Term ACE Inhibitor/ARB Use Is Associated with Severe Renal Dysfunction and Acute Kidney Injury in Patients with severe COVID-19: Results from a Referral Center Cohort in the North East of France. Clinical infectious diseases : an official publication of the Infectious Diseases Society of America 2020:D0I: 10.1093/cid/ciaa1677.

37. Gan J, Li J, Li S, Yang C: Leucocyte Subsets Effectively Predict the Clinical Outcome of Patients With COVID-19 Pneumonia: A Retrospective Case-Control Study. Frontiers in public health 2020, 8:299.

38. Chen J, Bai H, Liu J, Chen G, Liao Q, Yang J, Wu P, Wei J, Ma D, Chen G et al: Distinct clinical characteristics and risk factors for mortality in female CoVID19 inpatients: a sex-stratified large-scale cohort study in Wuhan, China. Clinical infectious diseases : an official publication of the Infectious Diseases Society of America 2020:DOI: 10.1093/cid/ciaa1920.

39. Ferrante G, Fazzari F, Cozzi O, Maurina M, Bragato R, D'Orazio F, Torrisi C, Lanza E, Indolfi E, Donghi V et al: Risk factors for myocardial injury and death in patients with COVID-19: insights from a cohort study with chest computed tomography. Cardiovascular research 2020:D0I: 10.1093/cvr/cvaa1193.

40. Rastad H, Karim H, Ejtahed HS, Tajbakhsh R, Noorisepehr M, Babaei M, Azimzadeh M, Soleimani A, Inanloo SH, Shafiabadi Hassani N et al: Risk and predictors of in-hospital mortality from COVID-19 in patients with diabetes and cardiovascular disease. Diabetology \& metabolic syndrome 2020, $12: 57$.

41. Hwang JM, Kim JH, Park JS, Chang MC, Park D: Neurological diseases as mortality predictive factors for patients with COVID-19: a retrospective cohort study. Neurological sciences : official journal of the Italian Neurological Society and of the Italian Society of Clinical Neurophysiology 2020, 41(9):23172324.

42. Grasselli G, Greco M, Zanella A, Albano G, Antonelli M, Bellani G, Bonanomi E, Cabrini L, Carlesso E, Castelli G et al: Risk Factors Associated With Mortality Among Patients With COVID-19 in Intensive Care Units in Lombardy, Italy. JAMA internal medicine 2020:D0I: 10.1001/jamainternmed.2020.3539.

43. Deng P, Ke Z, Ying B, Qiao B, Yuan L: The diagnostic and prognostic role of myocardial injury biomarkers in hospitalized patients with COVID-19. Clinica chimica acta; international journal of clinical chemistry 2020, 510:186-190.

44. Al-Salameh A, Lanoix JP, Bennis Y, Andrejak C, Brochot E, Deschasse G, Dupont H, Goeb V, Jaureguy M, Lion S et al: Characteristics and outcomes of COVID-19 in hospitalized patients with and without diabetes. Diabetes/metabolism research and reviews 2020:e3388.

Page $6 / 40$ 
45. Atkins JL, Masoli JAH, Delgado J, Pilling LC, Kuo CL, Kuchel GA, Melzer D: Preexisting Comorbidities Predicting COVID-19 and Mortality in the UK Biobank Community Cohort. The journals of gerontology Series A, Biological sciences and medical sciences 2020:D0I: 10.1093/gerona/glaa1183.

46. Yao JS, Paguio JA, Dee EC, Tan HC, Moulick A, Milazzo C, Jurado J, Della Penna N, Celi LA: The Minimal Effect of Zinc on the Survival of Hospitalized Patients With COVID-19: An Observational Study. Chest 2020:DOI: 10.1016/j.chest.2020.1006.1082.

47. Pinto C, Berselli A, Mangone L, Damato A, lachetta F, Foracchia M, Zanelli F, Gervasi E, Romagnani A, Prati G et al: SARS-CoV-2 Positive Hospitalized Cancer Patients during the Italian Outbreak: The Cohort Study in Reggio Emilia. Biology 2020, 9(8):DOI: 10.3390/biology9080181.

48. Chilimuri S, Sun H, Alemam A, Mantri N, Shehi E, Tejada J, Yugay A, Nayudu SK: Predictors of Mortality in Adults Admitted with CoVID-19: Retrospective Cohort Study from New York City. The western journal of emergency medicine 2020, 21(4):779-784.

49. Lian J, Jin C, Hao S, Zhang X, Yang M, Jin X, Lu Y, Hu J, Zhang S, Zheng L et al: High neutrophil-to-lymphocyte ratio associated with progression to critical illness in older patients with COVID-19: a multicenter retrospective study. Aging 2020, 12(14):13849-13859.

50. Zhao Z, Chen A, Hou W, Graham JM, Li H, Richman PS, Thode HC, Singer AJ, Duong TQ: Prediction model and risk scores of ICU admission and mortality in COVID-19. PloS one 2020, 15(7):e0236618.

51. Wang L, Foer D, Bates DW, Boyce JA, Zhou L: Risk factors for hospitalization, intensive care, and mortality among patients with asthma and CoVID-19. The Journal of allergy and clinical immunology 2020:DOI: 10.1016/j.jaci.2020.1007.1018.

52. Garcia-Azorin D, Martinez-Pias E, Trigo J, Hernandez-Perez I, Valle-Penacoba G, Talavera B, Simon-Campo P, de Lera M, Chavarria-Miranda A, Lopez-Sanz C et al: Neurological Comorbidity Is a Predictor of Death in Covid-19 Disease: A Cohort Study on 576 Patients. Frontiers in neurology 2020, 11:781.

53. Alkhatib AL, Kreniske J, Zifodya JS, Fonseca V, Tahboub M, Khatib J, Denson JL, Lasky JA, Lefante JJ, Bojanowski CM: BMI is Associated with Coronavirus Disease 2019 Intensive Care Unit Admission in African Americans. Obesity 2020:DOI: 10.1002/oby.22937.

54. Hernandez-Galdamez DR, Gonzalez-Block MA, Romo-Duenas DK, Lima-Morales R, Hernandez-Vicente IA, Lumbreras-Guzman M, Mendez-Hernandez P: Increased Risk of Hospitalization and Death in Patients with COVID-19 and Pre-existing Noncommunicable Diseases and Modifiable Risk Factors in Mexico. Archives of medical research 2020:DOI: 10.1016/j.arcmed.2020.1007.1003.

55. Bellmann-Weiler R, Lanser L, Barket R, Rangger L, Schapfl A, Schaber M, Fritsche G, Woll E, Weiss G: Prevalence and Predictive Value of Anemia and Dysregulated Iron Homeostasis in Patients with COVID-19 Infection. Journal of clinical medicine 2020, 9(8).

56. Berenguer J, Ryan P, Rodríguez-Baño J, Jarrín I, Carratalà J, Pachón J, Yllescas M, Arriba JR, Aznar Muñoz E, Gil Divasson P et al: Characteristics and predictors of death among 4035 consecutively hospitalized patients with COVID-19 in Spain. Clinical Microbiology and Infection 2020, 26(11):1525-1536.

57. Gottlieb M, Sansom S, Frankenberger C, Ward E, Hota B: Clinical Course and Factors Associated With Hospitalization and Critical Illness Among CoVID-19 Patients in Chicago, Illinois. Academic emergency medicine : official journal of the Society for Academic Emergency Medicine 2020:DOI: 10.1111/acem.14104.

58. Agarwal S, Schechter C, Southern W, Crandall JP, Tomer Y: Preadmission Diabetes-Specific Risk Factors for Mortality in Hospitalized Patients With Diabetes and Coronavirus Disease 2019. Diabetes care 2020:DOI: 10.2337/dc2320-1543.

59. Shang Y, Liu T, Wei Y, Li J, Shao L, Liu M, Zhang Y, Zhao Z, Xu H, Peng Z et al: Scoring systems for predicting mortality for severe patients with CoVID-19. EClinicalMedicine 2020, 24:100426.

60. Ciardullo S, Zerbini F, Perra S, Muraca E, Cannistraci R, Lauriola M, Grosso P, Lattuada G, Ippoliti G, Mortara A et al: Impact of diabetes on CoVID-19-related in-hospital mortality: a retrospective study from Northern Italy. Journal of endocrinological investigation 2020:D0I: 10.1007/s40618-40020-01382-40617.

61. Karbalai Saleh S, Oraii A, Soleimani A, Hadadi A, Shajari Z, Montazeri M, Moradi H, Talebpour M, Sadat Naseri A, Balali P et al: The association between cardiac injury and outcomes in hospitalized patients with COVID-19. Internal and emergency medicine 2020, 15(8):1415-1424.

62. Posso M, Comas M, Roman M, Domingo L, Louro J, Gonzalez C, Sala M, Angles A, Cirera I, Cots F et al: Comorbidities and Mortality in Patients With COVID-19 Aged 60 Years and Older in a University Hospital in Spain. Archivos de bronconeumologia 2020:D0I: 10.1016/j.arbres.2020.1006.1012.

63. Shu L, Wang X, Li M, Chen X, Ji N, Shi L, Wu M, Deng K, Wei J, Wang X et al: Clinical Characteristics of Moderate CoVID-19 Patients Aggravation in Wuhan Stadium Cabin Hospital: A 571 Cases of Retrospective Cohort Study. Journal of medical virology 2020:D0I: 10.1002/jmv.26414.

64. Parra-Bracamonte GM, Lopez-Villalobos N, Parra-Bracamonte FE: Clinical characteristics and risk factors for mortality of patients with CoVID-19 in a large dataset from Mexico. Annals of epidemiology 2020:DOI: 10.1016/j.annepidem.2020.1008.1005.

65. Pablos JL, Galindo M, Carmona L, Lledo A, Retuerto M, Blanco R, Gonzalez-Gay MA, Martinez-Lopez D, Castrejon I, Alvaro-Gracia JM et al: Clinical outcomes of hospitalised patients with COVID-19 and chronic inflammatory and autoimmune rheumatic diseases: a multicentric matched cohort study. Annals of the rheumatic diseases 2020:DOI: 10.1136/annrheumdis-2020-218296.

66. Zhang B, Liu S, Zhang L, Dong Y, Zhang S: Previous cardiovascular surgery significantly increases the risk of developing critical illness in patients with COVID-19. The Journal of infection 2020:DOI: 10.1016/j.jinf.2020.1008.1012.

67. Fox T, Ruddiman K, Lo KB, Peterson E, DeJoy R, 3rd, Salacup G, Pelayo J, Bhargav R, Gul F, Albano J et al: The relationship between diabetes and clinical outcomes in COVID-19: a single-center retrospective analysis. Acta diabetologica 2020:DOI: 10.1007/s00592-00020-01592-00598.

68. Vena A, Giacobbe DR, Di Biagio A, Mikulska M, Taramasso L, De Maria A, Ball L, Brunetti I, Loconte M, Patroniti NA et al: Clinical characteristics, management and in-hospital mortality of patients with coronavirus disease 2019 in Genoa, Italy. Clinical microbiology and infection : the official publication of the European Society of Clinical Microbiology and Infectious Diseases 2020:DOI: 10.1016/j.cmi.2020.1007.1049.

69. Ng JH, Hirsch JS, Wanchoo R, Sachdeva M, Sakhiya V, Hong S, Jhaveri KD, Fishbane S, Northwell C-RC, the Northwell Nephrology C-RC: Outcomes of patients with end-stage kidney disease hospitalized with COVID-19. Kidney international 2020:DOI: 10.1016/j.kint.2020.1007.1030.

70. He F, Luo Q, Lei M, Fan L, Shao X, Huang G, Zeng J, Zhao Z, Qin S, Yang Z et al: Risk factors for severe cases of COVID-19: a retrospective cohort study. Aging 2020, 12(15):15730-15740.

Page $7 / 40$ 
71. Gupta A, Madhavan MV, Poterucha TJ, DeFilippis EM, Hennessey JA, Redfors B, Eckhardt C, Bikdeli B, Platt J, Nalbandian A et al: Association Between Antecedent Statin Use and Decreased Mortality in Hospitalized Patients with COVID-19. Research square 2020.

72. Czernichow S, Beeker N, Rives-Lange C, Guerot E, Diehl JL, Katsahian S, Hulot JS, Poghosyan T, Carette C, Jannot AS: Obesity Doubles Mortality in Patients Hospitalized for Severe Acute Respiratory Syndrome Coronavirus 2 in Paris Hospitals, France: A Cohort Study on 5,795 Patients. Obesity 2020, 28(12):2282-2289.

73. Sisó-Almirall A, Kostov B, Mas-Heredia M, Vilanova-Rotllan S, Sequeira-Aymar E, Sans-Corrales M, Sant-Arderiu E, Cayuelas-Redondo L, Martínez-Pérez A, García-Plana N et al: Prognostic factors in Spanish COVID-19 patients: A case series from Barcelona. PloS one 2020, 15(8):e0237960.

74. Brenner H, Holleczek B, Schöttker B: Vitamin D insufficiency and deficiency and mortality from respiratory diseases in a cohort of older adults: Potential for limiting the death toll during and beyond the COVID-19 pandemic? Nutrients 2020, 12(8):1-11.

75. De Rossi N, Scarpazza C, Filippini C, Cordioli C, Rasia S, Mancinelli CR, Rizzoni D, Romanelli G, Cossi S, Vettoretto N et al: Early use of low dose tocilizumab in patients with COVID-19: A retrospective cohort study with a complete follow-up. EClinicalMedicine 2020, 25:100459.

76. Nimkar A, Naaraayan A, Hasan A, Pant S, Durdevic M, Suarez CN, Elenius H, Hambardzumyan A, Lakshmi K, Mandel M et al: Incidence and Risk Factors for Acute Kidney Injury and Its Effect on Mortality in Patients Hospitalized From COVID-19. Mayo Clinic proceedings Innovations, quality \& outcomes 2020, 4(6):687-695.

77. Klang E, Soffer S, Nadkarni G, Glicksberg B, Freeman R, Horowitz C, Reich DL, Levin MA: Sex Differences in Age and Comorbidities for CoVID-19 Mortality in Urban New York City. SN comprehensive clinical medicine 2020:1-4.

78. Emami A, Javanmardi F, Akbari A, Kojuri J, Bakhtiari H, Rezaei T, Keshavarzi A, Falahati F: Survival rate in hypertensive patients with CoVID-19. Clinical and Experimental Hypertension 2021, 43(1):77-80.

79. Liu D, Cui P, Zeng S, Wang S, Feng X, Xu S, Li R, Gao Y, Yu R, Wang Y et al: Risk factors for developing into critical COVID-19 patients in Wuhan, China: A multicenter, retrospective, cohort study. EClinicalMedicine 2020, 25:100471.

80. Rossi PG, Marino M, Formisano D, Venturelli F, Vicentini M, Grilli R, Reggio Emilia C-WG: Characteristics and outcomes of a cohort of CoVID-19 patients in the Province of Reggio Emilia, Italy. PloS one 2020, 15(8).

81. Feng X, Li P, Ma L, Liang H, Lei J, Li W, Wang K, Song Y, Li S, Yang W et al: Clinical Characteristics and Short-Term Outcomes of Severe Patients With COVID-19 in Wuhan, China. Frontiers in medicine 2020, 7:491.

82. Li G, Deng Q, Feng J, Li F, Xiong N, He Q: Clinical Characteristics of Diabetic Patients with COVID-19. Journal of diabetes research 2020, 2020:1652403.

83. Seiglie J, Platt J, Cromer SJ, Bunda B, Foulkes AS, Bassett IV, Hsu J, Meigs JB, Leong A, Putman MS et al: Diabetes as a Risk Factor for Poor Early Outcomes in Patients Hospitalized With COVID-19. Diabetes care 2020, 43(12):2938-2944.

84. Tural Onur S, Altın S, Sokucu SN, Fikri B, Barça T, Bolat E, Toptaş M: Could ferritin level be an indicator of COVID-19 disease mortality? Journal of medical virology 2021, 93(3):1672-1677.

85. Anzola GP, Bartolaminelli C, Gregorini GA, Coazzoli C, Gatti F, Mora A, Charalampakis D, Palmigiano A, De Simone M, Comini A et al: Neither ACEls nor ARBs are associated with respiratory distress or mortality in COVID-19 results of a prospective study on a hospital-based cohort. Internal and emergency medicine 2020, 15(8):1477-1484.

86. loannou GN, Locke E, Green P, Berry K, O'Hare AM, Shah JA, Crothers K, Eastment MC, Dominitz JA, Fan VS: Risk Factors for Hospitalization, Mechanical Ventilation, or Death Among 10131 US Veterans With SARS-CoV-2 Infection. JAMA network open 2020, 3(9):e2022310.

87. Bahl A, Van Baalen MN, Ortiz L, Chen NW, Todd C, Milad M, Yang A, Tang J, Nygren M, Qu L: Early predictors of in-hospital mortality in patients with COVID-19 in a large American cohort. Internal and emergency medicine 2020, 15(8):1485-1499.

88. Kabarriti R, Brodin NP, Maron MI, Guha C, Kalnicki S, Garg MK, Racine AD: Association of Race and Ethnicity with Comorbidities and Survival among Patients with COVID-19 at an Urban Medical Center in New York. JAMA Network Open 2020, 3(9).

89. Jackson BR, Gold JAW, Natarajan P, Rossow J, Neblett Fanfair R, da Silva J, Wong KK, Browning SD, Bamrah Morris S, Rogers-Brown J et al: Predictors at admission of mechanical ventilation and death in an observational cohort of adults hospitalized with COVID-19. Clinical infectious diseases : an official publication of the Infectious Diseases Society of America 2020.

90. Desai A, Voza G, Paiardi S, Teofilo Fl, Caltagirone G, Pons MR, Aloise M, Kogan M, Tommasini T, Savevski V et al: The role of anti-hypertensive treatment, comorbidities and early introduction of LMWH in the setting of COVID-19: A retrospective, observational study in Northern Italy. International journal of cardiology 2021, 324:249-254.

91. Wang X, Liu Z, Li J, Zhang J, Tian S, Lu S, Qi M, Ma J, Qiu B, Dong W et al: Impacts of Type 2 diabetes on disease severity, therapeutic effect, and mortality of patients with COVID-19. Journal of Clinical Endocrinology and Metabolism 2020, 105(12).

92. Solerte SB, D'Addio F, Trevisan R, Lovati E, Rossi A, Pastore I, Dell'Acqua M, Ippolito E, Scaranna C, Bellante R et al: Sitagliptin Treatment at the Time of Hospitalization Was Associated With Reduced Mortality in Patients With Type 2 Diabetes and COVID-19: A Multicenter, Case-Control, Retrospective, Observational Study. Diabetes care 2020, 43(12):2999-3006.

93. Hayek SS, Brenner SK, Azam TU, Shadid HR, Anderson E, Berlin H, Pan M, Meloche C, Feroz R, O'Hayer P et al: In-hospital cardiac arrest in critically ill patients with covid-19: multicenter cohort study. BMJ (Clinical research ed) 2020, 371:m3513.

94. Chen R, Yang J, Gao X, Ding X, Yang Y, Shen Y, He C, Xiang H, Ke J, Yuan F et al: Influence of blood pressure control and application of renin-angiotensinaldosterone system inhibitors on the outcomes in COVID-19 patients with hypertension. Journal of clinical hypertension (Greenwich, Conn) 2020, 22(11):1974-1983.

95. Lee JH, Kim YC, Cho SH, Lee J, You SC, Song YG, Won YB, Choi YS, Park YS: Effect of sex hormones on coronavirus disease 2019: an analysis of 5,061 laboratory-confirmed cases in South Korea. Menopause (New York, NY) 2020, 27(12):1376-1381.

Page $8 / 40$ 
96. Nachega JB, Ishoso DK, Otokoye JO, Hermans MP, Machekano RN, Sam-Agudu NA, Bongo-Pasi Nswe C, Mbala-Kingebeni P, Madinga JN, Mukendi S et al: Clinical Characteristics and Outcomes of Patients Hospitalized for COVID-19 in Africa: Early Insights from the Democratic Republic of the Congo. The American journal of tropical medicine and hygiene 2020, 103(6):2419-2428.

97. Rozaliyani A, Savitri Al, Setianingrum F, Shelly TN, Ratnasari V, Kuswindarti R, Salama N, Oktavia D, Widyastuti W, Handayani D: Factors Associated with Death in COVID-19 Patients in Jakarta, Indonesia: An Epidemiological Study. Acta medica Indonesiana 2020, 52(3):246-254.

98. Wang Z, Ye D, Wang M, Zhao M, Li D, Ye J, Liu J, Xu Y, Zhang J, Pan W et al: Clinical Features of COVID-19 Patients with Different Outcomes in Wuhan: A Retrospective Observational Study. BioMed research international 2020, 2020:2138387.

99. Liu L, Wei W, Yang K, Li S, Yu X, Dong C, Zhang B: Glycemic control before admission is an important determinant of prognosis in patients with coronavirus disease 2019. J Diabetes Investig 2020.

100. Al Kuwari HM, Abdul Rahim HF, Abu-Raddad LJ, Abou-Samra AB, Al Kanaani Z, Al Khal A, Al Kuwari E, Al Marri S, Al Masalmani M, Al Romaihi HE et al: Epidemiological investigation of the first 5685 cases of SARS-CoV-2 infection in Qatar, 28 February-18 April 2020. BMJ open 2020, 10(10).

101. Balbi M, Caroli A, Corsi A, Milanese G, Surace A, Di Marco F, Novelli L, Silva M, Lorini FL, Duca A et al: Chest X-ray for predicting mortality and the need for ventilatory support in COVID-19 patients presenting to the emergency department. European radiology 2020.

102. Calmes D, Graff S, Maes N, Frix AN, Thys M, Bonhomme O, Berg J, Debruche M, Gester F, Henket M et al: Asthma and COPD Are Not Risk Factors for ICU Stay and Death in Case of SARS-CoV2 Infection. The journal of allergy and clinical immunology In practice 2021, 9(1):160-169.

103. Talavera B, García-Azorín D, Martínez-Pías E, Trigo J, Hernández-Pérez I, Valle-Peñacoba G, Simón-Campo P, de Lera M, Chavarría-Miranda A, López-Sanz C et al: Anosmia is associated with lower in-hospital mortality in COVID-19. Journal of the Neurological Sciences 2020, 419.

104. Chatrath N, Kaza N, Pabari PA, Fox K, Mayet J, Barton C, Cole GD, Plymen CM: The effect of concomitant COVID-19 infection on outcomes in patients hospitalized with heart failure. ESC heart failure 2020, 7(6):4443-4447.

105. Mallow PJ, Belk KW, Topmiller M, Hooker EA: Outcomes of hospitalized COVID-19 patients by risk factors: Results from a United States hospital claims database. Journal of Health Economics and Outcomes Research 2020, 7(2):165-174.

106. Abbasi B, Akhavan R, Ghamari Khameneh A, Zandi B, Farrokh D, Pezeshki Rad M, Feyzi Laein A, Darvish A, Bijan B: Evaluation of the relationship between inpatient COVID-19 mortality and chest CT severity score. The American journal of emergency medicine 2020.

107. Craig-Schapiro R, Salinas T, Lubetzky M, Abel BT, Sultan S, Lee JR, Kapur S, Aull MJ, Dadhania DM: CoVID-19 outcomes in patients waitlisted for kidney transplantation and kidney transplant recipients. American journal of transplantation : official journal of the American Society of Transplantation and the American Society of Transplant Surgeons 2021, 21(4):1576-1585.

108. Ryan C, Minc A, Caceres J, Balsalobre A, Dixit A, Ng BK, Schmitzberger F, Syed-Abdul S, Fung C: Predicting severe outcomes in Covid-19 related illness using only patient demographics, comorbidities and symptoms. The American journal of emergency medicine 2020

109. Serin I, Sari ND, Dogu MH, Acikel SD, Babur G, Ulusoy A, Onar MI, Gokce EC, Altunok O, Yaylaci Mert F et al: A new parameter in COVID-19 pandemic: initial lactate dehydrogenase (LDH)/Lymphocyte ratio for diagnosis and mortality. Journal of infection and public health 2020, 13(11):1664-1670.

110. Cao Y, Han X, Gu J, Li Y, Liu J, Alwalid O, Cui Y, Zhang X, Zheng C, Fan Y et al: Prognostic value of baseline clinical and HRCT findings in 101 patients with severe COVID-19 in Wuhan, China. Scientific reports 2020, 10(1):17543.

111. Gupta S, Coca SG, Chan L, Melamed ML, Brenner SK, Hayek SS, Sutherland A, Puri S, Srivastava A, Leonberg-Yoo A et al: AKI Treated with Renal Replacement Therapy in Critically III Patients with COVID-19. Journal of the American Society of Nephrology : JASN2021, 32(1):161-176.

112. Raparelli V, Palmieri L, Canevelli M, Pricci F, Unim B, Lo Noce C, Villani ER, Rochon PA, Pilote L, Vanacore N et al: Sex differences in clinical phenotype and transitions of care among individuals dying of COVID-19 in Italy. Biology of sex differences 2020, 11(1):57.

113. Chinnadurai R, Ogedengbe O, Agarwal P, Money-Coomes S, Abdurrahman AZ, Mohammed S, Kalra PA, Rothwell N, Pradhan S: Older age and frailty are the chief predictors of mortality in COVID-19 patients admitted to an acute medical unit in a secondary care setting-a cohort study. BMC geriatrics 2020, 20(1):409.

114. Rajter JC, Sherman MS, Fatteh N, Vogel F, Sacks J, Rajter JJ: Use of Ivermectin Is Associated With Lower Mortality in Hospitalized Patients With Coronavirus Disease 2019: The Ivermectin in COVID Nineteen Study. Chest 2021, 159(1):85-92.

115. Naaraayan A, Nimkar A, Hasan A, Pant S, Durdevic M, Elenius H, Nava Suarez C, Basak P, Lakshmi K, Mandel M et al: End-Stage Renal Disease Patients on Chronic Hemodialysis Fare Better With COVID-19: A Retrospective Cohort Study From the New York Metropolitan Region. Cureus 2020, 12 (9):e10373.

116. Cherri S, Lemmers DHL, Noventa S, Abu Hilal M, Zaniboni A: Outcome of oncological patients admitted with COVID-19: experience of a hospital center in northern Italy. Therapeutic advances in medical oncology 2020, 12:1758835920962370.

117. Rodríguez-Molinero A, Gálvez-Barrón C, Miñarro A, Macho O, López GF, Robles MT, Dapena MD, Martínez S, Milà Ràfols N, Monaco EE et al: Association between COVID-19 prognosis and disease presentation, comorbidities and chronic treatment of hospitalized patients. PloS one 2020, 15 (10):e0239571.

118. Clift AK, Coupland CAC, Keogh RH, Hemingway H, Hippisley-Cox J: COVID-19 Mortality Risk in Down Syndrome: Results From a Cohort Study Of 8 Million Adults. Annals of internal medicine 2020

119. Clift AK, Coupland CAC, Keogh RH, Diaz-Ordaz K, Williamson E, Harrison EM, Hayward A, Hemingway H, Horby P, Mehta N et al: Living risk prediction algorithm (QCOVID) for risk of hospital admission and mortality from coronavirus 19 in adults: national derivation and validation cohort study. $B M J$ (Clinical research ed) 2020, 371:m3731.

120. Gamberini L, Tonetti T, Spadaro S, Zani G, Mazzoli CA, Capozzi C, Giampalma E, Bacchi Reggiani ML, Bertellini E, Castelli A et al: Factors influencing liberation from mechanical ventilation in coronavirus disease 2019: multicenter observational study in fifteen Italian ICUs. J Intensive Care 2020, 8:80.

121. Omrani AS, Almaslamani MA, Daghfal J, Alattar RA, Elgara M, Shaar SH, Ibrahim TBH, Zaqout A, Bakdach D, Akkari AM et al: The first consecutive 5000 patients with Coronavirus Disease 2019 from Qatar, a nation-wide cohort study. BMC infectious diseases 2020, 20(1):777.

Page $9 / 40$ 
122. Yahyavi A, Hemmati N, Derakhshan P, Banivaheb B, Karimi Behnagh A, Tofighi R, TehraniYazdi A, Kabir A: Angiotensin enzyme inhibitors and angiotensin receptor blockers as protective factors in COVID-19 mortality: a retrospective cohort study. Internal and emergency medicine 2020:1-11.

123. Ramos-Rincon JM, Buonaiuto V, Ricci M, Martín-Carmona J, Paredes-Ruíz D, Calderón-Moreno M, Rubio-Rivas M, Beato-Pérez JL, Arnalich-Fernández F, Monge-Monge $\mathrm{D}$ et al: Clinical Characteristics and Risk Factors for Mortality in Very Old Patients Hospitalized With COVID-19 in Spain. The journals of gerontology Series A, Biological sciences and medical sciences 2021, 76(3):e28-e37.

124. Izzy S, Tahir Z, Cote DJ, Al Jarrah A, Roberts MB, Turbett S, Kadar A, Smirnakis SM, Feske SK, Zafonte R et al: Characteristics and Outcomes of Latinx Patients With COVID-19 in Comparison With Other Ethnic and Racial Groups. Open forum infectious diseases 2020, 7(10):ofaa401.

125. Giorgi-Pierfranceschi M: Is aspirin effective in preventing ICU admission in patients with COVID-19 pneumonia? A comment to "Aspirin Use is Associated with Decreased Mechanical Ventilation, ICU Admission, and In-Hospital Mortality in Hospitalized Patients with COVID-19". Anesthesia and analgesia 2020, Publish Ahead of Print.

126. Raines AM, Tock JL, McGrew SJ, Ennis CR, Derania J, Jardak CL, Lim JH, Boffa JW, Houtsma C, Jones KR et al: Correlates of death among SARS-CoV-2 positive veterans: The contribution of lifetime tobacco use. Addictive behaviors 2021, 113:106692.

127. Zhang L, Fan T, Yang S, Feng H, Hao B, Lu Z, Xiong R, Shen X, Jiang W, Wang W et al: Comparison of clinical characteristics of CoVID-19 between elderly patients and young patients: a study based on a 28-day follow-up. Aging 2020, 12(20):19898-19910.

128. de Souza CD, de Arruda Magalhães AJ, Lima AJ, Nunes DN, de Fátima Machado Soares É, de Castro Silva L, Santos LG, Dos Santos Cardoso VI, Nobre YV, do Carmo RF: Clinical manifestations and factors associated with mortality from COVID-19 in older adults: Retrospective population-based study with 9807 older Brazilian COVID-19 patients. Geriatrics \& gerontology international 2020, 20(12):1177-1181.

129. Kolhe NV, Fluck RJ, Selby NM, Taal MW: Acute kidney injury associated with COVID-19: A retrospective cohort study. PLoS Medicine 2020, 17(10).

130. Kim TS, Roslin M, Wang JJ, Kane J, Hirsch JS, Kim EJ: BMI as a Risk Factor for Clinical Outcomes in Patients Hospitalized with CoVID-19 in New York. Obesity 2021, 29(2):279-284

131. Giustino G, Croft LB, Stefanini GG, Bragato R, Silbiger JJ, Vicenzi M, Danilov T, Kukar N, Shaban N, Kini A et al: Characterization of Myocardial Injury in Patients With COVID-19. Journal of the American College of Cardiology 2020, 76(18):2043-2055.

132. An C, Lim H, Kim DW, Chang JH, Choi YJ, Kim SW: Machine learning prediction for mortality of patients diagnosed with CoVID-19: a nationwide Korean cohort study. Scientific reports 2020, 10(1):18716.

133. Piazza G, Campia U, Hurwitz S, Snyder JE, Rizzo SM, Pfeferman MB, Morrison RB, Leiva O, Fanikos J, Nauffal V et al: Registry of Arterial and Venous Thromboembolic Complications in Patients With COVID-19. Journal of the American College of Cardiology 2020, 76(18):2060-2072.

134. Rao X, Wu C, Wang S, Tong S, Wang G, Wu G, Zhou R: The importance of overweight in COVID-19: A retrospective analysis in a single center of Wuhan, China. Medicine 2020, 99(43):e22766.

135. Ramadan HK, Mahmoud MA, Aburahma MZ, Elkhawaga AA, El-Mokhtar MA, Sayed IM, Hosni A, Hassany SM, Medhat MA: Predictors of Severity and CoInfection Resistance Profile in COVID-19 Patients: First Report from Upper Egypt. Infection and drug resistance 2020, 13:3409-3422.

136. Tehrani S, Killander A, Åstrand P, Jakobsson J, Gille-Johnson P: Risk factors for death in adult COVID-19 patients: Frailty predicts fatal outcome in older patients. International journal of infectious diseases : IJID : official publication of the International Society for Infectious Diseases 2021, 102:415-421.

137. Hyman JB, Leibner ES, Tandon P, Egorova NN, Bassily-Marcus A, Kohli-Seth R, Arvind V, Chang HL, Lin HM, Levin MA: Timing of Intubation and In-Hospital Mortality in Patients With Coronavirus Disease 2019. Critical care explorations 2020, 2(10):e0254.

138. Hamilton P, Hanumapura P, Castelino L, Henney R, Parker K, Kumar M, Murphy M, Al-Sayed T, Pinnington S, Felton T et al: Characteristics and outcomes of hospitalised patients with acute kidney injury and COVID-19. PloS one 2020, 15(11):e0241544.

139. Liu J, Zhang S, Dong X, Li Z, Xu Q, Feng H, Cai J, Huang S, Guo J, Zhang L et al: Corticosteroid treatment in severe COVID-19 patients with acute respiratory distress syndrome. The Journal of clinical investigation 2020, 130(12):6417-6428.

140. Ganatra S, Dani SS, Redd R, Rieger-Christ K, Patel R, Parikh R, Asnani A, Bang V, Shreyder K, Brar SS et al: Outcomes of CoVID-19 in Patients With a History of Cancer and Comorbid Cardiovascular Disease. Journal of the National Comprehensive Cancer Network : JNCCN 2020:1-10.

141. Rubio-Rivas M, Corbella X, Mora-Luján JM, Loureiro-Amigo J, López Sampalo A, Yera Bergua C, Esteve Atiénzar PJ, Díez García LF, Gonzalez Ferrer R, Plaza Canteli S et al: Predicting Clinical Outcome with Phenotypic Clusters in COVID-19 Pneumonia: An Analysis of 12,066 Hospitalized Patients from the Spanish Registry SEMI-COVID-19. Journal of clinical medicine 2020, 9(11).

142. Mendes A, Serratrice C, Herrmann FR, Genton L, Périvier S, Scheffler M, Fassier T, Huber P, Jacques MC, Prendki V et al: Predictors of In-Hospital Mortality in Older Patients With COVID-19: The COVIDAge Study. Journal of the American Medical Directors Association 2020, 21(11):1546-1554.e1543.

143. Nemer DM, Wilner BR, Burkle A, Aguilera J, Adewumi J, Gillombardo C, Wazni O, Menon V, Pengel S, Foxx M et al: Clinical Characteristics and Outcomes of Non-ICU Hospitalization for COVID-19 in a Nonepicenter, Centrally Monitored Healthcare System. Journal of hospital medicine 2021, 16(1):7-14.

144. Guo T, Shen Q, Zhou Z, Li J, Guo W, He W, Wang Y, Xiang Z, Huang P, Zeng N et al: Combined Interventions for Severe Novel Coronavirus Disease (CoVID19): Experience from 350 Patients. Infection and drug resistance 2020, 13:3907-3918.

145. Hilbrands LB, Duivenvoorden R, Vart P, Franssen CFM, Hemmelder MH, Jager KJ, Kieneker LM, Noordzij M, Pena MJ, Vries H et al: CoVID-19-related mortality in kidney transplant and dialysis patients: results of the ERACODA collaboration. Nephrology, dialysis, transplantation : official publication of the European Dialysis and Transplant Association - European Renal Association 2020, 35(11):1973-1983.

146. Wang F, Cao J, Yu Y, Ding J, Eshak ES, Liu K, Mubarik S, Shi F, Wen H, Zeng Z et al: Epidemiological characteristics of patients with severe CoVID-19 infection in Wuhan, China: evidence from a retrospective observational study. International journal of epidemiology 2021, 49(6):1940-1950.

147. Tang O, Bigelow BF, Sheikh F, Peters M, Zenilman JM, Bennett R, Katz MJ: Outcomes of Nursing Home CoVID-19 Patients by Initial Symptoms and Comorbidity: Results of Universal Testing of 1970 Residents. Journal of the American Medical Directors Association 2020, 21(12):1767-1773.e1761.

Page $10 / 40$ 
148. Huang Y, Lyu X, Li D, Wang L, Wang Y, Zou W, Wei Y, Wu X: A cohort study of 676 patients indicates D-dimer is a critical risk factor for the mortality of COVID-19. PloS one 2020, 15(11):e0242045.

149. Poterucha TJ, Elias P, Jain SS, Sayer G, Redfors B, Burkhoff D, Rosenblum H, Defilippis EM, Gupta A, Lawlor M et al: Admission Cardiac Diagnostic Testing with Electrocardiography and Troponin Measurement Prognosticates Increased 30-Day Mortality in COVID-19. Journal of the American Heart Association 2021, 10(1):e018476.

150. Li J, Zhang Y, Wang F, Liu B, Li H, Tang G, Chang Z, Liu A, Fu C, Lv Y et al: Cardiac damage in patients with the severe type of coronavirus disease 2019 (COVID-19). BMC cardiovascular disorders 2020, 20(1):479.

151. Prado-Galbarro FJ, Sanchez-Piedra C, Gamiño-Arroyo AE, Cruz-Cruz C: Determinants of survival after severe acute respiratory syndrome coronavirus 2 infection in Mexican outpatients and hospitalised patients. Public Health 2020, 189:66-72.

152. Shah C, Grando DJ, Rainess RA, Ayad L, Gobran E, Benson P, Neblett MT, Nookala V: Factors associated with increased mortality in hospitalized CoVID-19 patients. Annals of medicine and surgery (2012) 2020, 60:308-313.

153. Botta M, Tsonas AM, Pillay J, Boers LS, Algera AG, Bos LDJ, Dongelmans DA, Hollmann MW, Horn J, Vlaar APJ et al: Ventilation management and clinical outcomes in invasively ventilated patients with COVID-19 (PRoVENT-COVID): a national, multicentre, observational cohort study. The Lancet Respiratory medicine 2021, 9(2):139-148.

154. Di Domenico SL, Coen D, Bergamaschi M, Albertini V, Ghezzi L, Cazzaniga MM, Tombini V, Colombo R, Capsoni N, Coen T et al: Clinical characteristics and respiratory support of 310 COVID-19 patients, diagnosed at the emergency room: a single-center retrospective study. Internal and emergency medicine 2020:1-10.

155. Ayaz A, Arshad A, Malik H, Ali H, Hussain E, Jamil B: Risk factors for intensive care unit admission and mortality in hospitalized CoVID-19 patients. Acute and critical care 2020, 35(4):249-254.

156. Hippisley-Cox J, Young D, Coupland C, Channon KM, Tan PS, Harrison DA, Rowan K, Aveyard P, Pavord ID, Watkinson PJ: Risk of severe CoVID-19 disease with ACE inhibitors and angiotensin receptor blockers: cohort study including 8.3 million people. Heart (British Cardiac Society) 2020, 106(19):1503-1511.

157. Tomasoni D, Inciardi RM, Lombardi CM, Tedino C, Agostoni P, Ameri P, Barbieri L, Bellasi A, Camporotondo R, Canale C et al: Impact of heart failure on the clinical course and outcomes of patients hospitalized for COVID-19. Results of the Cardio-COVID-Italy multicentre study. European journal of heart failure 2020, 22(12):2238-2247.

158. Elmunzer BJ, Wolf BJ, Scheiman JM, Tierney WM, Taylor JR: Association Between Preadmission Acid Suppressive Medication Exposure and Severity of Illness in Patients Hospitalized With COVID-19. Gastroenterology 2021, 160(4):1417-1422.e1414.

159. Polverino F, Stern DA, Ruocco G, Balestro E, Bassetti M, Candelli M, Cirillo B, Contoli M, Corsico A, D'Amico F et al: Comorbidities, cardiovascular therapies, and COVID-19 mortality: A nationwide, italian observational study (ItaliCO). Frontiers in Cardiovascular Medicine 2020, 7.

160. Sharp AL, Huang BZ, Broder B, Smith M, Yuen G, Subject C, Nau C, Creekmur B, Tartof S, Gould MK: Identifying patients with symptoms suspicious for COVID-19 at elevated risk of adverse events: The COVAS score. The American journal of emergency medicine 2020.

161. Stebbing J, Sánchez Nievas G, Falcone M, Youhanna S, Richardson P, Ottaviani S, Shen JX, Sommerauer C, Tiseo G, Ghiadoni L et al: JAK inhibition reduces SARS-CoV-2 liver infectivity and modulates inflammatory responses to reduce morbidity and mortality. Science advances 2021, 7(1).

162. Fu L, Li XY, Fei J, Xiang Y, Xiang HX, Li MD, Liu FF, Li Y, Zhao H, Xu DX: Myocardial Injury at Early Stage and Its Association With the Risk of Death in COVID-19 Patients: A Hospital-Based Retrospective Cohort Study. Frontiers in cardiovascular medicine 2020, 7:590688.

163. Sheshah E, Sabico S, Albakr RM, Sultan AA, Alghamdi KS, Al Madani K, Alotair HA, Al-Daghri NM: Prevalence of diabetes, management and outcomes among Covid-19 adult patients admitted in a specialized tertiary hospital in Riyadh, Saudi Arabia. Diabetes research and clinical practice 2021, 172:108538.

164. Bowe B, Cai M, Xie Y, Gibson AK, Maddukuri G, Al-Aly Z: Acute Kidney Injury in a National Cohort of Hospitalized US Veterans with CoVID-19. Clinical journal of the American Society of Nephrology : CJASN 2020, 16(1):14-25.

165. Cheng X, Cai G, Wen X, Gao L, Jiang D, Sun M, Qin S, Zhou J, Zhang D: Clinical characteristics and fatal outcomes of hypertension in patients with severe COVID-19. Aging 2020, 12(23):23436-23449.

166. Neumann-Podczaska A, Chojnicki M, Karbowski LM, Al-Saad SR, Hashmi AA, Chudek J, Tobis S, Kropinska S, Mozer-Lisewska I, Suwalska A et al: Clinical Characteristics and Survival Analysis in a Small Sample of Older CoVID-19 Patients with Defined 60-Day Outcome. International journal of environmental research and public health 2020, 17(22).

167. Ken-Dror G, Wade C, Sharma S, Law J, Russo C, Sharma A, Joy E, John J, Robin J, John S et al: CoVID-19 outcomes in UK centre within highest health and wealth band: a prospective cohort study. BMJ open 2020, 10(11):e042090.

168. Iannelli A, Bouam S, Schneck AS, Frey S, Zarca K, Gugenheim J, Alifano M: The Impact of Previous History of Bariatric Surgery on Outcome of CoVID-19. A Nationwide Medico-Administrative French Study. Obesity surgery 2020:1-9.

169. Sharifpour M, Rangaraju S, Liu M, Alabyad D, Nahab FB, Creel-Bulos CM, Jabaley CS: C-Reactive protein as a prognostic indicator in hospitalized patients with COVID-19. PloS one 2020, 15(11):e0242400.

170. Martins-Filho PR, Antunes de Souza Araújo A, Pereira LX, Quintans-Júnior LJ, de Souza Barboza W, Cavalcante TF, Feitosa de Souza M, de Oliveira Góes MA, Santos VS: Factors Associated with Mortality among Hospitalized Patients with COVID-19: A Retrospective Cohort Study. The American journal of tropical medicine and hygiene 2021, 104(1):103-105.

171. Lee SG, Park GU, Moon YR, Sung K: Clinical Characteristics and Risk Factors for Fatality and Severity in Patients with Coronavirus Disease in Korea: A Nationwide Population-Based Retrospective Study Using the Korean Health Insurance Review and Assessment Service (HIRA) Database. International journal of environmental research and public health 2020, 17(22).

Page $11 / 40$ 
172. Loffi M, Piccolo R, Regazzoni V, Di Tano G, Moschini L, Robba D, Quinzani F, Esposito G, Franzone A, Danzi GB: Coronary artery disease in patients hospitalised with Coronavirus disease 2019 (COVID-19) infection. Open Heart 2020, 7(2).

173. Allameh SF, Nemati S, Ghalehtaki R, Mohammadnejad E, Aghili SM, Khajavirad N, Beigmohammadi MT, Salehi M, Mirfazaelian H, Edalatifard M et al: Clinical Characteristics and Outcomes of 905 COVID-19 Patients Admitted to Imam Khomeini Hospital Complex in the Capital City of Tehran, Iran. Archives of Iranian medicine 2020, 23(11):766-775.

174. Filardo TD, Khan MR, Krawczyk N, Galitzer H, Karmen-Tuohy S, Coffee M, Schaye VE, Eckhardt BJ, Cohen GM: Comorbidity and clinical factors associated with COVID-19 critical illness and mortality at a large public hospital in New York City in the early phase of the pandemic (March-April 2020). PloS one 2020, 15(11 November).

175. Grodecki K, Lin A, Razipour A, Cadet S, McElhinney PA, Chan C, Pressman BD, Julien P, Maurovich-Horvat P, Gaibazzi N et al: Epicardial adipose tissue is associated with extent of pneumonia and adverse outcomes in patients with COVID-19. Metabolism: clinical and experimental 2021, 115:154436.

176. Papageorgiou N, Providencia R, Saberwal B, Sohrabi C, Tyrlis A, Atieh AE, Lim WY, Creta A, Khanji M, Rusinova R et al: Ethnicity and CoVID-19 cardiovascular complications: a multi-center UK cohort. American journal of cardiovascular disease 2020, 10(4):455-462.

177. Khan A, Althunayyan S, Alsofayan Y, Alotaibi R, Mubarak A, Arafat M, Assiri A, Jokhdar H: Risk factors associated with worse outcomes in CoVID-19: a retrospective study in Saudi Arabia. Eastern Mediterranean health journal = La revue de sante de la Mediterranee orientale = al-Majallah al-sihhiyah Iisharq al-mutawassit 2020, 26(11):1371-1380.

178. Rutten JJS, van Loon AM, van Kooten J, van Buul LW, Joling KJ, Smalbrugge M, Hertogh C: Clinical Suspicion of CoVID-19 in Nursing Home Residents: Symptoms and Mortality Risk Factors. Journal of the American Medical Directors Association 2020, 21(12):1791-1797.e1791.

179. Schuelter-Trevisol F, Raimundo LJ, Soccas HD, Antunes AF, Mohr RLD, Marcon CEM, Trevisol DJ: Assessment of patients with COVID-19 hospitalized in southern Santa Catarina. Revista da Sociedade Brasileira de Medicina Tropica/ 2020, 53:1-5.

180. Severity of COVID-19 and survival in patients with rheumatic and inflammatory diseases: data from the French RMD COVID-19 cohort of 694 patients Annals of the rheumatic diseases 2020, 80(4):527-538.

181. Nyabera A, Lakhdar S, Li M, Trandafirescu T, Ouedraogo Tall S: The Association Between BMI and Inpatient Mortality Outcomes in Older Adults With CoVID-19. Cureus 2020, 12(10):e11183.

182. Ozturk S, Turgutalp K, Arici M, Odabas AR, Altiparmak MR, Aydin Z, Cebeci E, Basturk T, Soypacaci Z, Sahin G et al: Mortality analysis of CoVID-19 infection in chronic kidney disease, haemodialysis and renal transplant patients compared with patients without kidney disease: A nationwide analysis from Turkey. Nephrology Dialysis Transplantation 2021, 35(12):2083-2095.

183. Druyan A, Lidar M, Brodavka M, Levy I, Barzilai A, Pavlotsky F: The risk for severe COVID 19 in patients with autoimmune and/or inflammatory diseases: First wave lessons. Dermatologic therapy 2021, 34(1):e14627.

184. Alguwaihes AM, Al-Sofiani ME, Megdad M, Albader SS, Alsari MH, Alelayan A, Alzahrani SH, Sabico S, Al-Daghri NM, Jammah AA: Diabetes and Covid-19 among hospitalized patients in Saudi Arabia: a single-centre retrospective study. Cardiovascular diabetology 2020, $19(1): 205$.

185. Özdemir i H, Özlek B, Özen MB, Gündüz R, Çetin N, Bilge AR: Hydroxychloroquine/azithromycin treatment, QT interval and ventricular arrhythmias in hospitalised patients with COVID-19. International journal of clinical practice 2021, 75(2):e13896.

186. Gue YX, Tennyson M, Gao J, Ren S, Kanji R, Gorog DA: Development of a novel risk score to predict mortality in patients admitted to hospital with CoVID19. Scientific reports $2020,10(1): 21379$.

187. Galiero R, Pafundi PC, Simeon V, Rinaldi L, Perrella A, Vetrano E, Caturano A, Alfano M, Beccia D, Nevola R et al: Impact of chronic liver disease upon admission on COVID-19 in-hospital mortality: Findings from COVOCA study. PloS one 2020, 15(12):e0243700.

188. Rosenthal N, Cao Z, Gundrum J, Sianis J, Safo S: Risk Factors Associated With In-Hospital Mortality in a US National Sample of Patients With COVID-19. JAMA network open 2020, 3(12):e2029058.

189. Rethemiotaki I: A preliminary study of coronavirus disease 2019 in China: the impact of cardiovascular disease on death risk. Archives of medical sciences Atherosclerotic diseases 2020, 5:e219-e223.

190. Anca PS, Toth PP, Kempler P, Rizzo M: Gender differences in the battle against CoVID-19: Impact of genetics, comorbidities, inflammation and lifestyle on differences in outcomes. International journal of clinical practice 2021, 75(2):e13666.

191. Zhou S, Chen C, Hu Y, Lv W, Ai T, Xia L: Chest CT imaging features and severity scores as biomarkers for prognostic prediction in patients with COVID-19. Annals of translational medicine 2020, 8(21):1449.

192. Stefan G, Mehedinti AM, Andreiana I, Zugravu AD, Cinca S, Busuioc R, Miler I, Stancu S, Petrescu L, Dimitriu I et al: Clinical features and outcome of maintenance hemodialysis patients with COVID-19 from a tertiary nephrology care center in Romania. Renal failure 2021, 43(1):49-57.

193. Eshrati B, Baradaran HR, Erfanpoor S, Mohazzab A, Moradi Y: Investigating the factors affecting the survival rate in patients with COVID-19: A retrospective cohort study. Medical journal of the Islamic Republic of Iran 2020, 34:88.

194. Özyılmaz S, Ergün Alış E, Ermiş E, Allahverdiyev S, Uçar H: Assessment of the Relationship between Mortality and Troponin I Levels in Hospitalized Patients with the Novel Coronavirus (COVID-19). Medicina (Kaunas, Lithuania) 2020, 56(12).

195. Tan X, Zhang S, Xu J, Zhou M, Huang Q, Duan L, Lv Z, Xia H, Xiao W, Yin Z et al: Comparison of clinical characteristics among younger and elderly deceased patients with COVID-19: a retrospective study. Aging 2020, 13(1):16-26.

196. Ling SF, Broad E, Murphy R, Pappachan JM, Pardesi-Newton S, Kong MF, Jude EB: High-Dose Cholecalciferol Booster Therapy is Associated with a Reduced Risk of Mortality in Patients with COVID-19: A Cross-Sectional Multi-Centre Observational Study. Nutrients 2020, 12(12).

197. Zhong Y, Zhao L, Wu G, Hu C, Wu C, Xu M, Dong H, Zhang Q, Wang G, Yu B et al: Impact of renin-angiotensin system inhibitors use on mortality in severe COVID-19 patients with hypertension: a retrospective observational study. The Journal of international medical research 2020, 48(12):300060520979151.

Page $12 / 40$ 
198. Izurieta HS, Graham DJ, Jiao Y, Hu M, Lu Y, Wu Y, Chillarige Y, Wernecke M, Menis M, Pratt D et al: Natural history of CoVID-19: Risk factors for hospitalizations and deaths among >26 million U.S. Medicare beneficiaries. The Journal of infectious diseases 2020.

199. Burrell AJ, Pellegrini B, Salimi F, Begum H, Broadley T, Campbell LT, Cheng AC, Cheung W, Cooper DJ, Earnest A et al: Outcomes for patients with COVID-19 admitted to Australian intensive care units during the first four months of the pandemic. The Medical journal of Australia 2021, 214(1):23-30.

200. Caliskan T, Saylan B: Smoking and comorbidities are associated with COVID-19 severity and mortality in 565 patients treated in Turkey: a retrospective observational study. Revista da Associacao Medica Brasileira (1992) 2020, 66(12):1679-1684.

201. Moradi EV, Teimouri A, Rezaee R, Morovatdar N, Foroughian M, Layegh P, Kakhki BR, Koupaei SRA, Ghorani V: Increased age, neutrophil-to-lymphocyte ratio (NLR) and white blood cells count are associated with higher COVID-19 mortality. American Journal of Emergency Medicine 2021, 40:11-14.

202. The first wave of the COVID-19 pandemic in Spain: characterisation of cases and risk factors for severe outcomes, as at 27 April 2020 . Euro surveillance bulletin Europeen sur les maladies transmissibles = European communicable disease bulletin 2020, 25(50).

203. Rashidi F, Barco S, Kamangar F, Heresi GA, Emadi A, Kaymaz C, Jansa P, Reis A, Rashidi A, Taghizadieh A et al: Incidence of symptomatic venous thromboembolism following hospitalization for coronavirus disease 2019: Prospective results from a multi-center study. Thrombosis research 2021, 198:135-138.

204. Chaudhri I, Koraishy FM, Bolotova O, Yoo J, Marcos LA, Taub E, Sahib H, Bloom M, Ahmad S, Skopicki H et al: Outcomes Associated with the Use of ReninAngiotensin-Aldosterone System Blockade in Hospitalized Patients with SARS-CoV-2 Infection. Kidney360 2020, 1(8):801-809.

205. Huh K, Ji W, Kang M, Hong J, Bae GH, Lee R, Na Y, Jung J: Association of prescribed medications with the risk of COVID-19 infection and severity among adults in South Korea. International journal of infectious diseases : IJID : official publication of the International Society for Infectious Diseases 2021, 104:7-14

206. Orioli L, Servais T, Belkhir L, Laterre PF, Thissen JP, Vandeleene B, Maiter D, Yombi JC, Hermans MP: Clinical characteristics and short-term prognosis of inpatients with diabetes and COVID-19: A retrospective study from an academic center in Belgium. Diabetes \& metabolic syndrome 2021, 15(1):149-157.

207. Gude-Sampedro F, Fernández-Merino C, Ferreiro L, Lado-Baleato Ó, Espasandín-Domínguez J, Hervada X, Cadarso CM, Valdés L: Development and validation of a prognostic model based on comorbidities to predict COVID-19 severity: a population-based study. International journal of epidemiology 2021, 50(1):64-74.

208. Monteiro AC, Suri R, Emeruwa IO, Stretch RJ, Cortes-Lopez RY, Sherman A, Lindsay CC, Fulcher JA, Goodman-Meza D, Sapru A et al: Obesity and smoking as risk factors for invasive mechanical ventilation in COVID-19: A retrospective, observational cohort study. PloS one 2020, 15 (12):e0238552.

209. Lano G, Braconnier A, Bataille S, Cavaille G, Moussi-Frances J, Gondouin B, Bindi P, Nakhla M, Mansour J, Halin P et al: Risk factors for severity of CoVID19 in chronic dialysis patients from a multicentre French cohort. Clinical kidney journal 2020, 13(5):878-888.

210. Lanini S, Montaldo C, Nicastri E, Vairo F, Agrati C, Petrosillo N, Scognamiglio P, Antinori A, Puro V, Di Caro A et al: COVID-19 disease - Temporal analyses of complete blood count parameters over course of illness, and relationship to patient demographics and management outcomes in survivors and nonsurvivors: A longitudinal descriptive cohort study. PloS one 2020, 15(12 December).

211. Schwartz KL, Achonu C, Buchan SA, Brown KA, Lee B, Whelan M, Wu JHC, Garber G: Epidemiology, clinical characteristics, household transmission, and lethality of severe acute respiratory syndrome coronavirus-2 infection among healthcare workers in Ontario, Canada. PloS one 2020, 15(12 December).

212. Schwartz KL, Achonu C, Buchan SA, Brown KA, Lee B, Whelan M, Wu JH, Garber G: Epidemiology, clinical characteristics, household transmission, and lethality of severe acute respiratory syndrome coronavirus-2 infection among healthcare workers in Ontario, Canada. PloS one 2020, $15(12)$ :e0244477.

213. Sun Y, Guan X, Jia L, Xing N, Cheng L, Liu B, Zhang S, He K: Independent and combined effects of hypertension and diabetes on clinical outcomes in patients with COVID-19: A retrospective cohort study of Huoshen Mountain Hospital and Guanggu Fangcang Shelter Hospital. Journal of clinical hypertension (Greenwich, Conn) 2021, 23(2):218-231.

214. McGurnaghan SJ, Weir A, Bishop J, Kennedy S, Blackbourn LAK, McAllister DA, Hutchinson S, Caparrotta TM, Mellor J, Jeyam A et al: Risks of and risk factors for COVID-19 disease in people with diabetes: a cohort study of the total population of Scotland. The lancet Diabetes \& endocrinology 2021, $9(2): 82-93$

215. Cetinkal G, Kocas BB, Ser OS, Kilci H, Yildiz SS, Ozcan SN, Verdi Y, Altinay M, Kilickesmez K: The Association between Chronic Use of Renin-AngiotensinAldosterone System Blockers and in-Hospital Adverse Events among COVID-19 Patients with Hypertension. Sisli Etfal Hastanesi tip bulteni 2020, 54(4):399-404

216. Xu M, Yang W, Huang T, Zhou J: Diabetic patients with COVID-19 need more attention and better glycemic control. World journal of diabetes 2020, 11(12):644-653.

217. Lv Z, Lv S: Clinical characteristics and analysis of risk factors for disease progression of COVID-19: A retrospective Cohort Study. International journal of biological sciences 2021, 17(1):1-7.

218. Guerra Veloz MF, Cordero Ruiz P, Ríos-Villegas MJ, Del Pino Bellido P, Bravo-Ferrer J, Galvés Cordero R, Cadena Herrera ML, Vías Parrado C, Bellido Muñoz $\mathrm{F}$, Vega Rodríguez $\mathrm{F}$ et al: Liver manifestations in COVID-19 and the influence of preexisting liver disease in the course of the infection. Revista espanola de enfermedades digestivas : organo oficial de la Sociedad Espanola de Patologia Digestiva 2021, 113(2):103-109.

219. Clark A, Jit M, Warren-Gash C, Guthrie B, Wang HHX, Mercer SW, Sanderson C, McKee M, Troeger C, Ong KL et al: Global, regional, and national estimates of the population at increased risk of severe COVID-19 due to underlying health conditions in 2020: a modelling study. The Lancet Global health 2020:DOI: 10.1016/s2214-1109x(1020)30264-30263.

220. Guan WJ, Liang WH, Zhao Y, Liang HR, Chen ZS, Li YM, Liu XQ, Chen RC, Tang CL, Wang T et al: Comorbidity and its impact on 1590 patients with CoVID19 in China: a nationwide analysis. The European respiratory journal 2020, 55(5):DOI: 10.1183/13993003.13900547-13992020. 
221. Badawi A, Ryoo SG: Prevalence of comorbidities in the Middle East respiratory syndrome coronavirus (MERS-CoV): a systematic review and metaanalysis. International journal of infectious diseases : IJID : official publication of the International Society for Infectious Diseases 2016, 49:129-133.

\section{Tables}

Table 1 Main characteristics of the included studies 


\begin{tabular}{|c|c|c|c|c|c|c|c|}
\hline Author (Year) & Country & Patients(n) & $\begin{array}{l}\text { Mean/Median } \\
\text { Age(years) }\end{array}$ & Male (\%) & Study design & Kinds of diseases & CVD (\%) \\
\hline $\begin{array}{l}\text { Zhou et al. } \\
(2020)\end{array}$ & China & 191 & $\begin{array}{l}56 \cdot 0(46 \cdot 0- \\
67 \cdot 0)\end{array}$ & $119(62)$ & $\begin{array}{l}\text { Retrospective } \\
\text { cohort study }\end{array}$ & $\begin{array}{l}\text { Coronary heart } \\
\text { disease }\end{array}$ & $18(8)$ \\
\hline $\begin{array}{l}\text { Yu et al. } \\
(2020)\end{array}$ & China & 333 & $50 \otimes 35-63 \rrbracket$ & $172(51.7)$ & $\begin{array}{l}\text { Descriptive } \\
\text { study }\end{array}$ & heart disease & $24(7.2)$ \\
\hline $\begin{array}{l}\text { Cummings et al. } \\
(2020)\end{array}$ & USA & 257 & $62(51-72)$ & $171(67 \rrbracket$ & $\begin{array}{l}\text { Prospective } \\
\text { observational } \\
\text { cohort study t }\end{array}$ & $\begin{array}{l}\text { Chronic cardiac } \\
\text { disease }\end{array}$ & 49 (19) \\
\hline $\begin{array}{l}\text { Zhao et al. } \\
(2020)\end{array}$ & China & 1000 & $61(46-70)$ & $466(46.6 \rrbracket$ & $\begin{array}{l}\text { Retrospective } \\
\text { study }\end{array}$ & $\begin{array}{l}\text { Coronary heart } \\
\text { disease }\end{array}$ & $60(6)$ \\
\hline $\begin{array}{l}\text { Sabri et al. } \\
(2020)\end{array}$ & Iran & 60 & $54.1 \pm 15.5$ & NR & $\begin{array}{l}\text { Retrospective } \\
\text { cohort study }\end{array}$ & Heart Disease & $\begin{array}{l}10 \\
(15.9)\end{array}$ \\
\hline $\begin{array}{l}\text { Lala et al. } \\
(2020)\end{array}$ & USA & 2736 & 66.4 & $1630(59.6)$ & NR & $\begin{array}{l}\text { Coronary Artery } \\
\text { Disease }\end{array}$ & $\begin{array}{l}453 \\
(16.6)\end{array}$ \\
\hline $\begin{array}{l}\text { Cen et al. } \\
(2020)\end{array}$ & China & 1007 & $61(49-68)$ & $493(49.0)$ & $\begin{array}{l}\text { Multi-center } \\
\text { observational } \\
\text { study }\end{array}$ & $\begin{array}{l}\text { Coronary artery } \\
\text { disease }\end{array}$ & $65(6.5)$ \\
\hline $\begin{array}{l}\text { Ciceri et al. } \\
(2020)\end{array}$ & Italy & 410 & $65(56-75)$ & $299(72.9)$ & NR & $\begin{array}{l}\text { Coronary artery } \\
\text { disease }\end{array}$ & $\begin{array}{l}51 \\
(12.6)\end{array}$ \\
\hline $\begin{array}{l}\text { Barman et al. } \\
(2020)\end{array}$ & Turkey & 607 & $59.5 \pm 14.8$ & $334(55.02)$ & $\begin{array}{l}\text { Multi-center } \\
\text { retrospective } \\
\text { study }\end{array}$ & $\begin{array}{l}\text { Coronary artery } \\
\text { disease }\end{array}$ & $\begin{array}{l}116 \\
(19.1)\end{array}$ \\
\hline $\begin{array}{l}\text { Bravi et al. } \\
(2020)\end{array}$ & Italy & 1603 & $58.0 \pm 20.9$ & $758(47.3)$ & $\begin{array}{l}\text { Case-control, } \\
\text { retrospective } \\
\text { study }\end{array}$ & $\begin{array}{l}\text { Major } \\
\text { cardiovascular } \\
\text { diseases }\end{array}$ & $\begin{array}{l}258 \\
(16.1)\end{array}$ \\
\hline $\begin{array}{l}\text { Deiana et al. } \\
(2020)\end{array}$ & Italy & 1223 & $80.4 \pm 10.6$ & $499(40.8)$ & $\begin{array}{l}\text { Matched case- } \\
\text { control study }\end{array}$ & CVD & $\begin{array}{l}63 \\
(64.9)\end{array}$ \\
\hline $\begin{array}{l}\text { Zhang et al. } \\
(2020)\end{array}$ & China & 80 & $51.16 \pm 17.476$ & $33(41.25)$ & $\begin{array}{l}\text { Retrospective } \\
\text { cohort }\end{array}$ & Cardiac disease & $\begin{array}{l}9 \\
(11.25)\end{array}$ \\
\hline $\begin{array}{l}\text { Nie et al. } \\
(2020)\end{array}$ & China & 671 & $43 \pm 15.09$ & $377(56.2)$ & NR & CVD & $\begin{array}{l}70 \\
(10.4)\end{array}$ \\
\hline
\end{tabular}

Robilotti et al.

USA

423

60.2

212 (50)

NR

Cardiac disorder

$84(20)$ 


\begin{tabular}{|c|c|c|c|c|c|c|c|}
\hline $\begin{array}{l}\text { Hashemi et al. } \\
(2020)\end{array}$ & USA & 363 & $63.2 \pm 13.2$ & 201 (55.37) & $\begin{array}{l}\text { Multi-center } \\
\text { retrospective } \\
\text { study }\end{array}$ & Cardiac diseases & $\begin{array}{l}39 \\
(10.7)\end{array}$ \\
\hline $\begin{array}{l}\text { Lanza et al. } \\
(2020)\end{array}$ & Italy & 222 & $\begin{array}{l}66.4(53.8- \\
75.8)\end{array}$ & $163(73)$ & $\begin{array}{l}\text { Observational } \\
\text { retrospective } \\
\text { study, }\end{array}$ & Heart disease & $\begin{array}{l}27 \\
(12.16)\end{array}$ \\
\hline $\begin{array}{l}\text { Zeng et al. } \\
(2020)\end{array}$ & China & 461 & $\begin{array}{l}45.00(34.50- \\
57.00)\end{array}$ & $239(51.84)$ & $\begin{array}{l}\text { Multicenter } \\
\text { retrospective } \\
\text { study }\end{array}$ & CVD & $\begin{array}{l}25 \\
(5.42)\end{array}$ \\
\hline $\begin{array}{l}\text { Petrilli et al. } \\
(2020)\end{array}$ & USA & 5279 & $54(38-66)$ & $2615(49.5)$ & $\begin{array}{l}\text { Prospective } \\
\text { cohort study }\end{array}$ & $\begin{array}{l}\text { Coronary artery } \\
\text { disease }\end{array}$ & $\begin{array}{l}704 \\
(13.3)\end{array}$ \\
\hline $\begin{array}{l}\text { Arshad et al. } \\
\text { (2020) }\end{array}$ & USA & 2541 & $63.7 \pm 16.5$ & $1298(51.1)$ & $\begin{array}{l}\text { Retrospective } \\
\text { cohort study }\end{array}$ & $\begin{array}{l}\text { Cardiovascular } \\
\text { Comorbidity }\end{array}$ & $\begin{array}{l}222 \\
(8.7)\end{array}$ \\
\hline
\end{tabular}

\begin{tabular}{|c|c|c|c|c|c|c|c|}
\hline $\begin{array}{l}\text { San Román et al. } \\
(2020)\end{array}$ & Spain & 522 & $68 \pm 15$ & $294 \otimes 56 \rrbracket$ & NR & Heart disease & $\begin{array}{l}68 \\
(13.02)\end{array}$ \\
\hline $\begin{array}{l}\text { Cheng et al. } \\
(2020)\end{array}$ & China & 456 & $54.97 \pm 18.59$ & $211(46.27)$ & $\begin{array}{l}\text { Retrospective } \\
\text { cohort study }\end{array}$ & CVD & $\begin{array}{l}52 \\
(11.4)\end{array}$ \\
\hline
\end{tabular}

\begin{tabular}{|c|c|c|c|c|c|c|c|}
\hline $\begin{array}{l}\text { Oussalah et al. } \\
(2020)\end{array}$ & France & 149 & $65(54-77)$ & 91 (61.1) & $\begin{array}{l}\text { Retrospective, } \\
\text { longitudinal } \\
\text { cohort study }\end{array}$ & CVD & $\begin{array}{l}38 \\
(25.5)\end{array}$ \\
\hline $\begin{array}{l}\text { Kim et al. } \\
(2020)\end{array}$ & Korea & 9148 & $51 *$ & 3556 (38.9) & $\begin{array}{l}\text { Observational } \\
\text { Study }\end{array}$ & Heart failure & $\begin{array}{l}124 \\
(1.4)\end{array}$ \\
\hline $\begin{array}{l}\text { Chen et al. } \\
(2020)\end{array}$ & China & 3309 & $62(49-69)$ & $1642(49.6)$ & Retrospective & CVD & $\begin{array}{l}242 \\
(7.3)\end{array}$ \\
\hline
\end{tabular}

\begin{tabular}{|c|c|c|c|c|c|c|c|}
\hline $\begin{array}{l}\text { Ferrante et al. } \\
(2020)\end{array}$ & Italy & 332 & $\begin{array}{l}66.9(55.4- \\
75.5)\end{array}$ & 237 (71.4) & $\begin{array}{l}\text { Single-center } \\
\text { cohort study }\end{array}$ & CAD & $\begin{array}{l}49 \\
(14.5)\end{array}$ \\
\hline $\begin{array}{l}\text { Rastad et al. } \\
(2020)\end{array}$ & Iran & 2597 & $54.8 \pm 16.9$ & $1589 \llbracket 53.7 \rrbracket$ & $\begin{array}{l}\text { Retrospective } \\
\text { cohort study }\end{array}$ & CVD & $\begin{array}{l}314 \\
(10.6)\end{array}$ \\
\hline $\begin{array}{l}\text { Hwang et al. } \\
(2020)\end{array}$ & South Korea & 103 & $67.62 \pm 15.32$ & $52(50)$ & $\begin{array}{l}\text { Retrospective } \\
\text { cohort study }\end{array}$ & CVD & $12(12)$ \\
\hline $\begin{array}{l}\text { Grasselli ei al. } \\
(2020)\end{array}$ & Italy & 3988 & $63(56-69)$ & 3188 (79.9) & $\begin{array}{l}\text { Retrospective, } \\
\text { observational } \\
\text { cohort study }\end{array}$ & Heart disease & $\begin{array}{l}533 \\
(13.4)\end{array}$ \\
\hline
\end{tabular}




\begin{tabular}{|c|c|c|c|c|c|c|c|}
\hline $\begin{array}{l}\text { Deng et al. } \\
(2020)\end{array}$ & China & 264 & $\begin{array}{l}64.5(53.3- \\
74.0)\end{array}$ & $130(49.2)$ & $\begin{array}{l}\text { Retrospective } \\
\text { study }\end{array}$ & $\begin{array}{l}\text { Coronary heart } \\
\text { disease }\end{array}$ & $\begin{array}{l}32 \\
(12.1)\end{array}$ \\
\hline $\begin{array}{l}\text { Al-Salameh et al. } \\
(2020)\end{array}$ & France & 433 & $72 \pm 14.3$ & $226(52.1)$ & $\begin{array}{l}\text { Observational } \\
\text { cohort }\end{array}$ & CVD & $\begin{array}{l}99 \\
(31.2)\end{array}$ \\
\hline $\begin{array}{l}\text { Atkins et al. } \\
(2020)\end{array}$ & UK & 507 & $74.3 \pm 4.5$ & $311 \rrbracket 61.3 \rrbracket$ & NR & $\mathrm{CHD}$ & $\begin{array}{l}108 \\
(21.5)\end{array}$ \\
\hline $\begin{array}{l}\text { Yao et al. } \\
(2020)\end{array}$ & USA & 242 & $66.1 \pm 18.3$ & $104(42.98 \rrbracket$ & $\begin{array}{l}\text { Single- } \\
\text { institution } \\
\text { retrospective } \\
\text { study }\end{array}$ & Heart Disease & $\begin{array}{l}39 \\
(13.6)\end{array}$ \\
\hline $\begin{array}{l}\text { Pinto et al. } \\
(2020)\end{array}$ & Italy & 1226 & $71.7 \pm 14.5$ & $733(59.8)$ & $\begin{array}{l}\text { Observational } \\
\text { cohort Study }\end{array}$ & CVD & NR (NR) \\
\hline $\begin{array}{l}\text { Chilimuri et al. } \\
(2020)\end{array}$ & USA & 375 & $\begin{array}{l}63.0(52.0- \\
72.0)\end{array}$ & $236(63)$ & $\begin{array}{l}\text { Retrospective } \\
\text { cohort study }\end{array}$ & CVD & $62(17)$ \\
\hline $\begin{array}{l}\text { Lian et al. } \\
(2020)\end{array}$ & China & 232 & NR & $108(46.5)$ & $\begin{array}{l}\text { Retrospective } \\
\text { study }\end{array}$ & Heart disease & $\begin{array}{l}31 \\
(13.36)\end{array}$ \\
\hline $\begin{array}{l}\text { Zhao et al. } \\
(2020)\end{array}$ & USA & 641 & $58.9 \pm 17.5$ & $358(55.85)$ & $\begin{array}{l}\text { Retrospective } \\
\text { study }\end{array}$ & Heart failure & $\begin{array}{l}20 \\
(3.12)\end{array}$ \\
\hline $\begin{array}{l}\text { Wang et al. } \\
(2020)\end{array}$ & USA & 1827 & $52.7 \pm 21.1$ & $500(32.6)$ & NR & CVD & $\begin{array}{l}589 \\
(32.2)\end{array}$ \\
\hline Garcia-Azoin et al. (2020) & Spain & 576 & $67.18 \pm 14.75$ & $326(56.6)$ & $\begin{array}{l}\text { Retrospective } \\
\text { cohort study }\end{array}$ & Cardiac disease & $\begin{array}{l}154 \\
(26.7)\end{array}$ \\
\hline $\begin{array}{l}\text { Alkhatib et al. } \\
(2020)\end{array}$ & USA & 158 & $57 \pm 15.1$ & $61(38.6)$ & $\begin{array}{l}\text { Retrospective } \\
\text { cross-sectional } \\
\text { analysis }\end{array}$ & Heart Failure & $\begin{array}{l}21 \\
(13.3)\end{array}$ \\
\hline $\begin{array}{l}\text { Hernández-Galdamez et al. } \\
\text { (2020) }\end{array}$ & Mexico & 211003 & $45.7 \pm 16.3$ & $\begin{array}{l}115442 \\
(54.71)\end{array}$ & $\begin{array}{l}\text { Cross- } \\
\text { sectional study }\end{array}$ & CVD & $\begin{array}{l}4949 \\
(2.35)\end{array}$ \\
\hline Bellmann-Weiler et al. (2020) & Australia & 259 & $66.8 \pm 14.3$ & $157(60.62)$ & Retrospective & CVD & $\begin{array}{l}152 \\
(58.62)\end{array}$ \\
\hline $\begin{array}{l}\text { Berenguer et al. } \\
(2020)\end{array}$ & Spain & 4035 & $70(56-80)$ & $2433(61)$ & $\begin{array}{l}\text { Retrospective } \\
\text { nationwide } \\
\text { cohort study }\end{array}$ & $\begin{array}{l}\text { Chronic heart } \\
\text { disease }\end{array}$ & $\begin{array}{l}932 \\
(23.3)\end{array}$ \\
\hline $\begin{array}{l}\text { Gottlieb et al. } \\
(2020)\end{array}$ & USA & 8673 & $41(29-54)$ & 4045 (46.6) & $\begin{array}{l}\text { Retrospective } \\
\text { case-control } \\
\text { study t }\end{array}$ & $\begin{array}{l}\text { Congestive Heart } \\
\text { Failure }\end{array}$ & $\begin{array}{l}218 \\
(14.7)\end{array}$ \\
\hline
\end{tabular}




\begin{tabular}{|c|c|c|c|c|c|c|c|}
\hline $\begin{array}{l}\text { Agarwal et al. } \\
(2020)\end{array}$ & USA & 1126 & $67.9 \pm 13.7$ & $630(49.3)$ & Retrospective & CVD & 754 (59) \\
\hline $\begin{array}{l}\text { Shang et al. } \\
(2020)\end{array}$ & China & 2529 & 66 & $73(64.6)$ & Retrospective & $\mathrm{CHD}$ & $\begin{array}{l}28 \\
(24.8)\end{array}$ \\
\hline $\begin{array}{l}\text { Shi et al. } \\
(2020)\end{array}$ & Iran & 386 & $59.46 \pm 15.82$ & $236(61.1)$ & $\begin{array}{l}\text { Prospective, } \\
\text { single-center } \\
\text { study }\end{array}$ & CVD & 97(25.1) \\
\hline $\begin{array}{l}\text { Posso et al. } \\
(2020)\end{array}$ & Spain & 834 & 60 & $400(46.5)$ & Retrospective & Heart Failure & $\begin{array}{l}37 \\
(37.4)\end{array}$ \\
\hline $\begin{array}{l}\text { Shu et al. } \\
(2020)\end{array}$ & China & 571 & $\begin{array}{l}50.0(38.0- \\
59.0)\end{array}$ & $278(48.7)$ & $\begin{array}{l}\text { Single-center, } \\
\text { retrospective } \\
\text { cohort study }\end{array}$ & $\begin{array}{l}\text { Coronary heart } \\
\text { disease }\end{array}$ & $12(2.1)$ \\
\hline Parra-Bracamonte et al. (2020) & Mexico & 142690 & $45(34.0-57.0)$ & $79280(56)$ & NR & Cardiopathy & $\begin{array}{l}3521 \\
(2.0)\end{array}$ \\
\hline $\begin{array}{l}\text { Pablos et al. } \\
(2020)\end{array}$ & Spain & 456 & $65 \pm 17.9$ & $182(41)$ & $\begin{array}{l}\text { Retrospective } \\
\text { observational } \\
\text { matched } \\
\text { cohort study }\end{array}$ & Heart failure & $\begin{array}{l}106 \\
(23.2)\end{array}$ \\
\hline $\begin{array}{l}\text { Zhang et al. } \\
(2020)\end{array}$ & China & 461 & $51(38-64)$ & $264(57.3)$ & $\begin{array}{l}\text { Multicenter } \\
\text { study }\end{array}$ & $\begin{array}{l}\text { Coronary heart } \\
\text { disease }\end{array}$ & $25(5.4)$ \\
\hline $\begin{array}{l}\text { Fox et al. } \\
(2020)\end{array}$ & USA & 389 & $66.2 \pm 14.2$ & $208(46.5)$ & $\begin{array}{l}\text { Single-center } \\
\text { retrospective } \\
\text { analysis }\end{array}$ & CAD & $\begin{array}{l}77 \\
(19.79)\end{array}$ \\
\hline $\begin{array}{l}\text { Vena et al. } \\
(2020)\end{array}$ & Italy & 317 & $71(60-82)$ & $213(67.2)$ & $\begin{array}{l}\text { Retrospective } \\
\text { study }\end{array}$ & CVD & $\begin{array}{l}63 \\
(19.9)\end{array}$ \\
\hline $\begin{array}{l}\mathrm{Ng} \text { et al. } \\
(2020)\end{array}$ & USA & 10482 & 66 & $6239(59.5)$ & $\begin{array}{l}\text { Retrospective } \\
\text { study }\end{array}$ & Heart Failure & $\begin{array}{l}920 \\
(8.78)\end{array}$ \\
\hline $\begin{array}{l}\text { He et al. } \\
(2020)\end{array}$ & China & 288 & $48.5(34.3-62)$ & $131(45.5)$ & $\begin{array}{l}\text { Single-center, } \\
\text { retrospective } \\
\text { cohort study }\end{array}$ & CVD & $\begin{array}{l}85 \\
(29.5)\end{array}$ \\
\hline $\begin{array}{l}\text { Gupta et al. } \\
(2020)\end{array}$ & USA & 2626 & $63.99 \pm 16.49$ & 1497(57.00) & $\begin{array}{l}\text { Retrospective } \\
\text { study }\end{array}$ & CAD & $\begin{array}{l}516 \\
(19.6)\end{array}$ \\
\hline $\begin{array}{l}\text { Czernichow et al. } \\
(2020)\end{array}$ & Europe & 5795 & $59.8 \pm 13.6$ & 3791 (65.4) & $\begin{array}{l}\text { Prospective } \\
\text { cohort study }\end{array}$ & HF & $\begin{array}{l}264 \\
(4.55)\end{array}$ \\
\hline $\begin{array}{l}\text { Sisó-Almirall et al. } \\
(2020)\end{array}$ & Spain & 322 & $56.7 \pm 17.8$ & $161(50.0)$ & $\begin{array}{l}\text { Multicenter, } \\
\text { observational } \\
\text { descriptive } \\
\text { study }\end{array}$ & $\mathrm{HF}$ & $25(7.8)$ \\
\hline $\begin{array}{l}\text { Brenner et al*. } \\
(2020)\end{array}$ & Germany & 9548 & 62.1 & $4182(43.8)$ & $\begin{array}{l}\text { Ongoing } \\
\text { statewide } \\
\text { cohort study }\end{array}$ & CVD & $\begin{array}{l}4186 \\
(43.8)\end{array}$ \\
\hline De Rossi et al. & Italy & 158 & $66.38 \pm 13.44$ & 113 (71.52囚 & Retrospective & Heart disease & 33 \\
\hline
\end{tabular}




\begin{tabular}{|c|c|c|c|c|c|c|c|}
\hline $\begin{array}{l}\text { Nimkar et al. } \\
\text { (2020) }\end{array}$ & USA & 327 & $71(59-82)$ & $182(55.7)$ & $\begin{array}{l}\text { Retrospective } \\
\text { case series }\end{array}$ & Cardiac Disease & $\begin{array}{l}98 \\
(29.9)\end{array}$ \\
\hline $\begin{array}{l}\text { Klang et al. } \\
(2020)\end{array}$ & USA & 1320 & $74.48 \pm 12.88$ & $772(58.48)$ & $\begin{array}{l}\text { Multicenter } \\
\text { observational } \\
\text { retrospective } \\
\text { study }\end{array}$ & $\mathrm{CHD}$ & $\begin{array}{l}258 \\
(19.55)\end{array}$ \\
\hline $\begin{array}{l}\text { Emami et al. } \\
\text { (2021) }\end{array}$ & Iran & 1239 & $51.48 \pm 19.54$ & $692(55.9)$ & NR & CVD & $\begin{array}{l}132 \\
(10.7)\end{array}$ \\
\hline $\begin{array}{l}\text { Liu et al. } \\
\text { (2020) }\end{array}$ & China & 2044 & $\begin{array}{l}62.0(51.0- \\
70.0)\end{array}$ & $\begin{array}{l}1000 \\
(48.92)\end{array}$ & $\begin{array}{l}\text { Mini-national } \\
\text { multicenter, } \\
\text { retrospective, } \\
\text { cohort study }\end{array}$ & $\mathrm{CHD}$ & $\begin{array}{l}199 \\
(9.76)\end{array}$ \\
\hline $\begin{array}{l}\text { Giorgi et al. } \\
(2020)\end{array}$ & Italy & 2653 & 63.2 & $1328(50.1)$ & $\begin{array}{l}\text { Population- } \\
\text { based } \\
\text { prospective } \\
\text { cohort }\end{array}$ & $\mathrm{CHD}$ & $\begin{array}{l}168 \\
(7.1)\end{array}$ \\
\hline $\begin{array}{l}\text { Feng et al. } \\
(2020)\end{array}$ & China & 114 & $63.96 \pm 13.41$ & $71(62.3)$ & $\begin{array}{l}\text { Single-center, } \\
\text { prospective } \\
\text { study }\end{array}$ & CVD & $\begin{array}{l}31 \\
(27.2)\end{array}$ \\
\hline Li et al. & China & 199 & 67 (61-78) & $89(44.7)$ & $\begin{array}{l}\text { Retrospective } \\
\text { study }\end{array}$ & CVD & NR (NR) \\
\hline
\end{tabular}

$\begin{array}{lllllll}\text { Seiglie et al. } & \text { USA } & 450 & 63.32 \pm 17.13 & 259(57.5) & \begin{array}{l}\text { Observational } \\ \text { study }\end{array} & \text { CHF }\end{array}$

\begin{tabular}{|c|c|c|c|c|c|c|c|}
\hline Tural Onur et al. (2020) & Turkey & 301 & $57 \pm 18$ & $206(68.4)$ & Retrospectively & CVD & $19(6.3)$ \\
\hline $\begin{array}{l}\text { Anzola et al. } \\
(2020)\end{array}$ & Italy & 431 & $65 \pm 16$ & $263(61)$ & $\begin{array}{l}\text { Prospective } \\
\text { study }\end{array}$ & CVD & $77(18)$ \\
\hline loannou et al. & USA & 10131 & $61.6 \pm 15.9$ & $9221(91.0)$ & $\begin{array}{l}\text { Longitudinal } \\
\text { cohort study }\end{array}$ & CAD & $\begin{array}{l}2203 \\
(21.7)\end{array}$ \\
\hline
\end{tabular}

(2020)

$\begin{array}{llllll}\text { Bahl et al. } & \text { USA } & 1461 & \begin{array}{l}62.0(50.0- \\ 74.0)\end{array} & 770(52.7) & \begin{array}{l}\text { Multicentered } \\ \text { cohort study }\end{array} \\ \begin{array}{llll}\text { (2020) } & & & \text { CVD }\end{array}\end{array}$

\begin{tabular}{|c|c|c|c|c|c|c|c|}
\hline $\begin{array}{l}\text { Kabarriti et al. } \\
(2020)\end{array}$ & USA & 5902 & $58(44-71)$ & 2768 (46.9) & Cohort study & CVD & $\begin{array}{l}1306 \\
(22.1)\end{array}$ \\
\hline $\begin{array}{l}\text { Jackson et al. } \\
(2020)\end{array}$ & USA & 51 & $60(45-69)$ & $29(56.9)$ & $\begin{array}{l}\text { Retrospective } \\
\text { observational } \\
\text { cohort }\end{array}$ & CAD & $\begin{array}{l}10 \\
(19.6)\end{array}$ \\
\hline $\begin{array}{l}\text { Desai et al. } \\
(2020)\end{array}$ & Italy & 575 & 64.8 (27-93) & 380 (66.09) & $\begin{array}{l}\text { Single-center, } \\
\text { retrospective, } \\
\text { observational } \\
\text { study }\end{array}$ & CVD & $\begin{array}{l}155 \\
(27.1)\end{array}$ \\
\hline
\end{tabular}




\begin{tabular}{|c|c|c|c|c|c|c|c|}
\hline $\begin{array}{l}\text { Wang et al. } \\
(2021)\end{array}$ & China & 663 & $58(44-69)$ & 321 (48.4) & Retrospective & CVD & $\begin{array}{l}164 \\
(24.7)\end{array}$ \\
\hline $\begin{array}{l}\text { Solerte et al. } \\
(2020)\end{array}$ & Italy & 169 & $69 \pm 1.0$ & 115 (68) & $\begin{array}{l}\text { Multicenter, } \\
\text { case-control, } \\
\text { retrospective, } \\
\text { observational } \\
\text { study }\end{array}$ & CVD & $53(38)$ \\
\hline $\begin{array}{l}\text { Hayek et al. } \\
(2020)\end{array}$ & USA & 5019 & $60.42 \pm 14.86$ & $\begin{array}{l}3165 \\
(63.06)\end{array}$ & $\begin{array}{l}\text { Multicenter } \\
\text { cohort study }\end{array}$ & CAD & $\begin{array}{l}676 \\
(13.47)\end{array}$ \\
\hline
\end{tabular}

\begin{tabular}{|c|c|c|c|c|c|c|c|}
\hline $\begin{array}{l}\text { Chen et al. } \\
\text { (2020) }\end{array}$ & China & 2828 & $\begin{array}{l}60.0(50.0- \\
68.0)\end{array}$ & $1442(51.0)$ & $\begin{array}{l}\text { single-center } \\
\text { Retrospective } \\
\text { cohort study }\end{array}$ & $\mathrm{CHD}$ & $\begin{array}{l}181 \\
(6.4)\end{array}$ \\
\hline
\end{tabular}

\begin{tabular}{|c|c|c|c|c|c|c|c|}
\hline $\begin{array}{l}\text { Lee et al. } \\
(2020)\end{array}$ & South Korea & 5061 & $45.44 \pm 17.92$ & $2,229(44 \%)$ & $\begin{array}{l}\text { Retrospective } \\
\text { cohort study }\end{array}$ & CVD & $\begin{array}{l}49 \\
(0.97)\end{array}$ \\
\hline $\begin{array}{l}\text { Nachega et al. } \\
(2020)\end{array}$ & South Africa & 766 & $46(34-58)$ & $500(65.6)$ & $\begin{array}{l}\text { Retrospective } \\
\text { cohort study }\end{array}$ & Heart disease & $30(3.9)$ \\
\hline
\end{tabular}

$\begin{array}{llllll}\text { Rozaliyani et al. } & \text { India } & 4052 & 45.8 \pm 16.3 & 2169(53.5) & \begin{array}{l}\text { Retrospective } \\ \text { cohort study }\end{array}\end{array}$




\begin{tabular}{|c|c|c|c|c|c|c|c|}
\hline $\begin{array}{l}\text { Liu et al. } \\
(2020)\end{array}$ & China & 77 & $63.6 \pm 3.6$ & $48(62)$ & $\begin{array}{l}\text { Retrospective } \\
\text { study }\end{array}$ & CVD & $15(20)$ \\
\hline $\begin{array}{l}\text { Al Kuwari et al. } \\
(2020)\end{array}$ & Qatar & 5685 & $35.8 \pm 12.0$ & 5052 (88.9) & Case series & CVD & $\begin{array}{l}250 \\
(4.4)\end{array}$ \\
\hline $\begin{array}{l}\text { Balbi et al. } \\
(2020)\end{array}$ & Italy & 340 & $68(57-76)$ & $252(74)$ & $\begin{array}{l}\text { Retrospective } \\
\text { observational } \\
\text { study }\end{array}$ & CVD & $86(25)$ \\
\hline $\begin{array}{l}\text { Calmes et al. } \\
(2021)\end{array}$ & Belgium & 493 & $58 \pm 19$ & $244(49.49 \rrbracket$ & NR & Cardiopathy & $88(18)$ \\
\hline $\begin{array}{l}\text { Talavera et al. } \\
(2020)\end{array}$ & Spain & 576 & $67.18 \pm 14.75$ & $325(56.6)$ & $\begin{array}{l}\text { Retrospective } \\
\text { cohort study }\end{array}$ & $\begin{array}{l}\text { Cardiological } \\
\text { disorders }\end{array}$ & $\begin{array}{l}154 \\
(26.7)\end{array}$ \\
\hline $\begin{array}{l}\text { Zinellu et al. } \\
(2020)\end{array}$ & Italy & 105 & $\begin{array}{l}72.0(59.5- \\
80.0)\end{array}$ & 70 (66.67》 & Retrospective & CVD & $\begin{array}{l}59 \\
(56.19)\end{array}$ \\
\hline Mallow et al. & USA & 21676 & $64.9 \pm 17.2$ & $\begin{array}{l}11442 \\
(52.8)\end{array}$ & $\begin{array}{l}\text { Retrospective } \\
\text { cohort study }\end{array}$ & $\begin{array}{l}\text { Severe heart } \\
\text { disease }\end{array}$ & $\begin{array}{l}12000 \\
(55.4)\end{array}$ \\
\hline
\end{tabular}

$\begin{array}{llllll}\text { Abbasi et al. } & \text { Iran } & 262 & 58(43-67) & 172(65.6) & \begin{array}{l}\text { Retrospective } \\ \text { cohort study }\end{array} \\ (2020) & & & & \begin{array}{l}78 \\ (29.8)\end{array}\end{array}$

$\begin{array}{llllllllll}\text { Craig-Schapiro et al. (2021) } & \text { USA } & 136 & 56.24 \pm 35.04 & 93(68.38) & \text { NR } & \text { CVD } & \text { (38.23) }\end{array}$

$\begin{array}{llcccc}\text { Ryan et al. } & \text { USA } & 556 & 57 \pm 17 & 296(53) & \begin{array}{l}\text { Retrospective } \\ \text { case-control } \\ \text { study }\end{array}\end{array}$

$\begin{array}{lllllllll}\text { Serin et al. } & \text { Turkey } & 2217 & 47.66 \pm 17.23 & 1175(53) & \text { NR } & \text { CAD } & 165 \\ (2020) & & & & & & \end{array}$

\begin{tabular}{|c|c|c|c|c|c|c|c|}
\hline $\begin{array}{l}\text { Cao et al. } \\
(2020)\end{array}$ & China & 101 & $56.6 \pm 15.1$ & 67 (66.3) & $\begin{array}{l}\text { Retrospective, } \\
\text { two-center } \\
\text { study }\end{array}$ & CVD & $\begin{array}{l}21 \\
(20.8)\end{array}$ \\
\hline $\begin{array}{l}\text { Gupta et al. } \\
(2020)\end{array}$ & USA & 3099 & $62(51-71)$ & $2003(64.6)$ & $\begin{array}{l}\text { Multicenter } \\
\text { cohort study }\end{array}$ & CAD & $\begin{array}{l}390 \\
(12.6)\end{array}$ \\
\hline
\end{tabular}




\begin{tabular}{|c|c|c|c|c|c|c|c|}
\hline $\begin{array}{l}\text { Raparelli et al. } \\
(2021)\end{array}$ & Italy & 3517 & $77.64 \pm 11.51$ & $2346(66.7)$ & $\begin{array}{l}\text { Retrospective } \\
\text { analysis }\end{array}$ & $\begin{array}{l}\text { Congestive Heart } \\
\text { Failure }\end{array}$ & $\begin{array}{l}539 \\
(15.7)\end{array}$ \\
\hline $\begin{array}{l}\text { Chinnadurai et al. } \\
\text { (2020) }\end{array}$ & UK & 215 & $74(60-82)$ & $133(61.9)$ & $\begin{array}{l}\text { Single-center } \\
\text { observational } \\
\text { study }\end{array}$ & CVD & $\begin{array}{l}93 \\
(43.3)\end{array}$ \\
\hline Rajter et al. & USA & 280 & $59.6 \pm 15.9$ & $153(64.6)$ & NR & cardiac Disease & $\begin{array}{l}43 \\
(15.4)\end{array}$ \\
\hline
\end{tabular}

\begin{tabular}{|c|c|c|c|c|c|c|c|}
\hline $\begin{array}{l}\text { Naaraayan ey al. } \\
(2020)\end{array}$ & USA & 362 & $71(59-82)$ & $200(55.3)$ & $\begin{array}{l}\text { Retrospective } \\
\text { case series }\end{array}$ & Cardiac diseases & $\begin{array}{l}119 \\
(32.9)\end{array}$ \\
\hline Cherri et al. (2020) & Italy & 53 & $75(68-83)$ & $32(60.4)$ & $\begin{array}{l}\text { Retrospective } \\
\text { study }\end{array}$ & Cardiopathy & $\begin{array}{l}20 \\
(37.7)\end{array}$ \\
\hline $\begin{array}{l}\text { Rodríguez-Molinero et al. } \\
(2020)\end{array}$ & Spain & 418 & $65.4 \pm 16.6$ & $238(56.9)$ & $\begin{array}{l}\text { Observational } \\
\text { cohort study }\end{array}$ & Heart failure & $\begin{array}{l}26 \\
(6.22)\end{array}$ \\
\hline $\begin{array}{l}\text { Clift et al. } \\
(2020)\end{array}$ & UK & 8256158 & $44.33 \pm 27.42$ & $\begin{array}{l}4111197 \\
(49.8)\end{array}$ & Cohort study & Heart failure & $\begin{array}{l}96225 \\
(1.17)\end{array}$ \\
\hline
\end{tabular}


Population based cohor study
Coronary heart disease
Gamberini et al.

(2020)
Italy

2540

$66(59-72)$

$300(76.7)$

Multicenter

prospective

observational

study

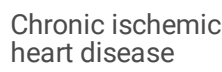

Chronic ischemic heart disease

$35(9)$

$\begin{array}{lll}\begin{array}{l}\text { Retrospective } \\ \text { cohort study }\end{array} & \begin{array}{l}\text { Coronary artery } \\ \text { disease }\end{array} & 31(2.4)\end{array}$

(2020)

1409

$39.82 \pm 14.2$

1167 (82.8)

cohort study

disease

Retrospective

CVD

942 Yahyavi et al.

Iran

2553

$58.1 \pm 17.9$

1498 (58.7) cohort study

(36.9)

(2020)

607

$69 \pm 22.0$

394 (65.02)

Retrospective, ongitudinal

chronic cardiac disease

study

Izzy et al.*

USA

5190

$52(36-66)$

2378 (46)

NR

Coronary artery

257 (5)

(2020) 


\begin{tabular}{|c|c|c|c|c|c|c|c|}
\hline $\begin{array}{l}\text { Chow et al. } \\
(2020)\end{array}$ & USA & 412 & $55(41-66)$ & $244(52.9)$ & $\begin{array}{l}\text { Retrospective, } \\
\text { observational } \\
\text { cohort study }\end{array}$ & CAD & $\begin{array}{l}52 \\
(12.62)\end{array}$ \\
\hline Raines et al. & USA & 440 & $60.8 \pm 14.07$ & 393 (89.32) & Retrospective & CVD & $\begin{array}{l}364 \\
(82.73)\end{array}$ \\
\hline
\end{tabular}

\begin{tabular}{|c|c|c|c|c|c|c|c|}
\hline Ramos-Rincon et al. (2020) & Spain & 2772 & $\begin{array}{l}86.3(83.2- \\
89.6)\end{array}$ & $1367(49.4)$ & $\begin{array}{l}\text { Nationwide, } \\
\text { multicenter, } \\
\text { retrospective, } \\
\text { observational } \\
\text { study }\end{array}$ & CVD & $\begin{array}{l}855 \\
(30.8)\end{array}$ \\
\hline
\end{tabular}

\begin{tabular}{|c|c|c|c|c|c|c|c|}
\hline $\begin{array}{l}\text { Zhang et al. } \\
\text { (2021) }\end{array}$ & China & 222 & $\begin{array}{l}51.5(34.0- \\
65.3)\end{array}$ & $90(40.54)$ & NR & $\begin{array}{l}\text { Chronic } \\
\text { cardiovascular } \\
\text { disease }\end{array}$ & $\begin{array}{l}44 \\
(19.82)\end{array}$ \\
\hline $\begin{array}{l}\text { de Souza et al. } \\
(2020)\end{array}$ & Brazil & 9807 & $70.21 \pm 8.37$ & $4662(47.5)$ & $\begin{array}{l}\text { Retrospective } \\
\text { population- } \\
\text { based study }\end{array}$ & CVD & $\begin{array}{l}1192 \\
(12.2)\end{array}$ \\
\hline
\end{tabular}

\begin{tabular}{|c|c|c|c|c|c|c|c|}
\hline $\begin{array}{l}\text { Kolhe et al. } \\
(2020)\end{array}$ & UK & 1161 & $72.1 \pm 16.0$ & 657 (56.59) & $\begin{array}{l}\text { Retrospective } \\
\text { cohort study }\end{array}$ & $\begin{array}{l}\text { Congestive cardiac } \\
\text { failure }\end{array}$ & $\begin{array}{l}207 \\
(17.83)\end{array}$ \\
\hline
\end{tabular}

$\begin{array}{lllllll}\text { Kim et al. } & \text { USA } & 10861 & 65(54-77) & 6468(59.6) & \text { NR } & \text { CAD } \\ \begin{array}{l}(2021) \\ \text { Giustino et al. }\end{array} & \begin{array}{l}\text { New York } \\ \text { City \& Milan }\end{array} & 305 & 63(53-73) & 205(67.2) & \begin{array}{l}\text { International, } \\ \text { multicenter } \\ \text { cohort study }\end{array}\end{array}$




\begin{tabular}{|c|c|c|c|c|c|c|c|}
\hline $\begin{array}{l}\text { An et al. } \\
(2020)\end{array}$ & Korea & 228 & $44.97 \pm 19.79$ & 107 (46.9) & Cohort study & CVD & $\begin{array}{l}70 \\
(30.7)\end{array}$ \\
\hline $\begin{array}{l}\text { Piazza et al. } \\
(2020)\end{array}$ & USA & 1114 & $50.6 \pm 18.3$ & $511(45.98$ & $\begin{array}{l}\text { Retrospective } \\
\text { observational } \\
\text { cohort } \\
\text { analysis }\end{array}$ & CAD & $90(8.1)$ \\
\hline $\begin{array}{l}\text { Rao et al. } \\
(2020)\end{array}$ & China & 240 & $48(23-87)$ & $111(46.250$ & $\begin{array}{l}\text { Retrospective } \\
\text { cohort study }\end{array}$ & CVD & $\begin{array}{l}43 \\
(17.9)\end{array}$ \\
\hline $\begin{array}{l}\text { Tehrani et al. } \\
\text { (2021) }\end{array}$ & Sweden. & 255 & $66 \pm 17$ & $150(59)$ & $\begin{array}{l}\text { Retrospective } \\
\text { analysis }\end{array}$ & $\begin{array}{l}\text { Chronic heart } \\
\text { failure }\end{array}$ & $34(13)$ \\
\hline $\begin{array}{l}\text { Hyman et al. } \\
(2020)\end{array}$ & USA & 755 & $63 \pm 13$ & $483(64.0)$ & $\begin{array}{l}\text { Retrospective } \\
\text { cohort study }\end{array}$ & $\begin{array}{l}\text { Congestive heart } \\
\text { failure or valve } \\
\text { disorder }\end{array}$ & $30(4.3)$ \\
\hline $\begin{array}{l}\text { Hamilton et al. } \\
(2020)\end{array}$ & UK & 1032 & $71(56-83)$ & $569(55.1)$ & $\begin{array}{l}\text { Retrospective } \\
\text { review }\end{array}$ & $\begin{array}{l}\text { Congestive Heart } \\
\text { Failure }\end{array}$ & $\begin{array}{l}129 \\
(12.5)\end{array}$ \\
\hline $\begin{array}{l}\text { Liu et al. } \\
\text { (2020) }\end{array}$ & China & 774 & $64(54-73)$ & $452(58.4)$ & $\begin{array}{l}\text { Multicenter } \\
\text { retrospective } \\
\text { observational } \\
\text { study }\end{array}$ & $\begin{array}{l}\text { Chronic cardiac } \\
\text { disease }\end{array}$ & $\begin{array}{l}91 \\
(11.8)\end{array}$ \\
\hline
\end{tabular}

\begin{tabular}{|c|c|c|c|c|c|c|c|}
\hline Ganatra et al. & USA & 2467 & $59(18-101)$ & $1032(42)$ & $\begin{array}{l}\text { Retrospective } \\
\text { study }\end{array}$ & CAD & $\begin{array}{l}184 \\
(7.0)\end{array}$ \\
\hline al. & Spain & 12066 & $68(56-79)$ & 7052 (58.5) & Cohort study & $\begin{array}{l}\text { Chronic heart } \\
\text { failure }\end{array}$ & $\begin{array}{l}809 \\
(6.7)\end{array}$ \\
\hline
\end{tabular}

(2020) failure

\begin{tabular}{llccccc}
$\begin{array}{l}\text { Mendes et al. } \\
(2020)\end{array}$ & Switzerland & 235 & $86.3 \pm 6.5$ & $102(43.4)$ & $\begin{array}{l}\text { Retrospective } \\
\text { monocentric } \\
\text { cohort study }\end{array}$ \\
$\begin{array}{l}\text { Nemer et al. } \\
(2020)\end{array}$ & USA & 350 & $64 \pm 16$ & $194(55)$ & $\begin{array}{l}\text { Heart failure } \\
(28.1)\end{array}$ \\
\hline
\end{tabular}

$\begin{array}{llllll}\text { Guo et al. } & \text { China } & 350 & 43(32-56) & 173(49.4) & \begin{array}{l}\text { Retrospective, } \\ \text { multicenter } \\ \text { study }\end{array} \\ \begin{array}{l}\text { (2020) } \\ \text { CVD }\end{array} & \text { 15 (4.3) }\end{array}$




\begin{tabular}{|c|c|c|c|c|c|c|c|}
\hline $\begin{array}{l}\text { Hilbrands et al. } \\
(2020)\end{array}$ & Netherlands & 305 & $60 \pm 13$ & $189(62)$ & $\begin{array}{l}\text { Observational } \\
\text { study }\end{array}$ & Heart failure & $64(21)$ \\
\hline $\begin{array}{l}\text { Wang et al. } \\
(2020)\end{array}$ & China & 7283 & $64(53-71)$ & $3732(51.2)$ & $\begin{array}{l}\text { Retrospective } \\
\text { observational } \\
\text { study }\end{array}$ & CVD & $\begin{array}{l}161 \\
(2.2)\end{array}$ \\
\hline $\begin{array}{l}\text { Tang et al. } \\
(2020)\end{array}$ & USA & 752 & $\begin{array}{l}73.9(21.9- \\
105.4)\end{array}$ & $323(43)$ & Cohort study & $\begin{array}{l}\text { Coronary heart } \\
\text { disease }\end{array}$ & $\begin{array}{l}240 \\
(31.91)\end{array}$ \\
\hline $\begin{array}{l}\text { Annweiler et al. } \\
(2020)\end{array}$ & France & 77 & $88(85-92)$ & $39(50.6)$ & $\begin{array}{l}\text { Retrospective } \\
\text { quasi- } \\
\text { experimental } \\
\text { study }\end{array}$ & Cardiomyopathy & $\begin{array}{l}42 \\
(54.5)\end{array}$ \\
\hline $\begin{array}{l}\text { Huang et al. } \\
(2020)\end{array}$ & China & 676 & $\begin{array}{l}56.0(39.0- \\
68.0)\end{array}$ & $314(46.4)$ & $\begin{array}{l}\text { Retrospective } \\
\text { study }\end{array}$ & Heart Disease & $\begin{array}{l}71 \\
(10.5)\end{array}$ \\
\hline $\begin{array}{l}\text { Poterucha et al. } \\
\text { (2021) }\end{array}$ & USA & 887 & 64.1 & $513(58)$ & $\begin{array}{l}\text { Retrospective } \\
\text { study }\end{array}$ & CAD & $\begin{array}{l}104 \\
(12.0)\end{array}$ \\
\hline $\begin{array}{l}\text { Li et al. } \\
(2020)\end{array}$ & China & 100 & $\begin{array}{l}62.0(51.0- \\
70.8)\end{array}$ & $56(56.0)$ & NR & CVD & $\begin{array}{l}15 \\
(15.0)\end{array}$ \\
\hline Prado-Galbarro et al. (2020) & Mexico & 9487 & $\begin{array}{l}31.37(41.13- \\
51.18)\end{array}$ & $5050(53.2)$ & $\begin{array}{l}\text { Observational } \\
\text { study }\end{array}$ & CVD & 171(1.8; \\
\hline $\begin{array}{l}\text { Shah et al. } \\
(2020)\end{array}$ & USA & 487 & $68.53 \pm 16.66$ & $273(56.06)$ & $\begin{array}{l}\text { Retrospective } \\
\text { review }\end{array}$ & Cardiomyopathy & $\begin{array}{l}16 \\
(3.28)\end{array}$ \\
\hline $\begin{array}{l}\text { Botta et al. } \\
(2021)\end{array}$ & Netherlands & 553 & $\begin{array}{l}67.0(59.0- \\
73.0)\end{array}$ & $417(75)$ & $\begin{array}{l}\text { National, } \\
\text { multicenter, } \\
\text { observational } \\
\text { cohort study }\end{array}$ & Heart failure & $25(5.0)$ \\
\hline Di Domenico et al. (2020) & France & 310 & $64(52-76)$ & $200(64.5)$ & $\begin{array}{l}\text { Single-center } \\
\text { retrospective } \\
\text { study }\end{array}$ & Heart disease & $\begin{array}{l}50 \\
(16.2)\end{array}$ \\
\hline $\begin{array}{l}\text { Ayaz et al. } \\
(2020)\end{array}$ & Pakistan & 66 & $50.6 \pm 19.1$ & $40(61)$ & $\begin{array}{l}\text { Retrospective } \\
\text { cohort study }\end{array}$ & $\begin{array}{l}\text { Ischemic heart } \\
\text { disease }\end{array}$ & $10(15)$ \\
\hline
\end{tabular}




$\begin{array}{llll}\begin{array}{l}\text { North } \\ \text { American }\end{array} & 1846 & 59.9 \pm 16.4 & 1044(56.6)\end{array}$

Large-scale retrospective cohort study

Congestive Heart

Failure

(2020) Italy

3179

$2171(68.3)$

\section{Nationwide} observational study

Coronary artery disease

(2020)

Sharp et al.

USA

21280

50 (34-66)

9053 (42.5)

Retrospective cohort study
NA (NA)
Congestive Heart
Failure

(2020) 


\begin{tabular}{|c|c|c|c|c|c|c|c|}
\hline $\begin{array}{l}\text { Cheng et al. } \\
(2020)\end{array}$ & China & 220 & $\begin{array}{l}59.5(48.3- \\
70.0)\end{array}$ & $106(48.2)$ & $\begin{array}{l}\text { Retrospective, } \\
\text { observational } \\
\text { study }\end{array}$ & CAD & $\begin{array}{l}22 \\
(10.0)\end{array}$ \\
\hline $\begin{array}{l}\text { Neumann-Podczaska et al. } \\
\text { (2020) }\end{array}$ & Poland & 50 & $74.8 \pm 9.4$ & $35(70.0)$ & Retrospective & Heart disease & $\begin{array}{l}26 \\
(52.0)\end{array}$ \\
\hline $\begin{array}{l}\text { Ken-Dror et al. } \\
(2020)\end{array}$ & UK & 429 & $70 \pm 18$ & $242(56.4 \rrbracket$ & $\begin{array}{l}\text { Prospective } \\
\text { cohort study }\end{array}$ & $\begin{array}{l}\text { chronic cardiac } \\
\text { disease/congenital } \\
\text { heart disease }\end{array}$ & $\begin{array}{l}103 \\
(31.3)\end{array}$ \\
\hline
\end{tabular}

\begin{tabular}{|c|c|c|c|c|c|c|c|}
\hline $\begin{array}{l}\text { lannelli et al. } \\
(2020)\end{array}$ & France & 8286 & $59.1 \pm 12.6$ & $4296(51.8)$ & Retrospective & Cardiac failure & $\begin{array}{l}569 \\
(6.9)\end{array}$ \\
\hline $\begin{array}{l}\text { Sharifpour et al. } \\
(2020)\end{array}$ & USA & 268 & $63 \pm 15$ & $149(55.6)$ & $\begin{array}{l}\text { Cohort } \\
\text { analysis }\end{array}$ & CAD & $\begin{array}{l}36 \\
(13.4)\end{array}$ \\
\hline Martins-Filho et al. (2020) & $\begin{array}{l}\text { Northeast } \\
\text { Brazil }\end{array}$ & 1207 & $60(46-73)$ & $724(60)$ & $\begin{array}{l}\text { Retrospective } \\
\text { cohort study }\end{array}$ & Heart failure & $\begin{array}{l}102 \\
(8.45)\end{array}$ \\
\hline $\begin{array}{l}\text { Lee et al. } \\
(2020)\end{array}$ & Korea & 7339 & $47.1 \pm 19.0$ & $2970(40.1)$ & $\begin{array}{l}\text { Nationwide } \\
\text { Population- } \\
\text { Based } \\
\text { Retrospective } \\
\text { Study }\end{array}$ & CVD & $\begin{array}{l}455 \\
(6.1)\end{array}$ \\
\hline
\end{tabular}

\begin{tabular}{|c|c|c|c|c|c|c|c|}
\hline $\begin{array}{l}\text { Loffi et al. } \\
(2020)\end{array}$ & Italy & 1252 & $64.7 \pm 15.5$ & 798 (63.74) & $\begin{array}{l}\text { Retrospective, } \\
\text { observational, } \\
\text { single-center } \\
\text { study }\end{array}$ & CAD & $\begin{array}{l}124 \\
(9.9)\end{array}$ \\
\hline $\begin{array}{l}\text { Grodecki et al. } \\
(2021)\end{array}$ & USA & 109 & $63.74 \pm 15.11$ & 68 (62.39) & Prospective & Heart failure & $\begin{array}{l}16 \\
(14.68)\end{array}$ \\
\hline
\end{tabular}

$\begin{array}{llllll}\text { Rossi et al. } & \text { Italy } & 590 & \begin{array}{l}76.2(68.2- \\ 82.6)\end{array} & 399(67.6) & \begin{array}{l}\text { Retrospective } \\ \text { observational } \\ \text { study }\end{array} \\ (2020) & & & & \text { CVD } & \text { (16.1) }\end{array}$

\begin{tabular}{|c|c|c|c|c|c|c|c|}
\hline Khan et al. & Saudi Arabia & 648 & $34 \pm 19$ & $342(52.8)$ & $\begin{array}{l}\text { Retrospective } \\
\text { cohort study }\end{array}$ & Cardiac diseases & $23(3.5)$ \\
\hline
\end{tabular}




\begin{tabular}{|c|c|c|c|c|c|c|c|}
\hline $\begin{array}{l}\text { Rutten et al. } \\
\text { (2020) }\end{array}$ & Netherlands & 1538 & $84 \pm 8.7$ & 554 (36.02) & $\begin{array}{l}\text { Prospective } \\
\text { cohort study }\end{array}$ & CVD & $\begin{array}{l}53 \\
(3.47)\end{array}$ \\
\hline Schuelter-Trevisol et al. (2020) & Brazil & 211 & $51.2^{\star}$ & $113(53.6)$ & Cohort study & $\begin{array}{l}\text { Chronic heart } \\
\text { disease }\end{array}$ & $\begin{array}{l}27 \\
(12.9)\end{array}$ \\
\hline
\end{tabular}

\begin{tabular}{|c|c|c|c|c|c|c|c|}
\hline $\begin{array}{l}\text { FAI2R } \\
\text { /SFR/SNFMI/SOFREMIP/CRI/IMIDIATE } \\
(2020)\end{array}$ & France & 694 & $56.1 \pm 16.4$ & $232(33.4)$ & $\begin{array}{l}\text { Observational, } \\
\text { multicenter, } \\
\text { French } \\
\text { national cohort } \\
\text { study }\end{array}$ & $\begin{array}{l}\text { Coronary heart } \\
\text { diseases }\end{array}$ & $68(9.8)$ \\
\hline $\begin{array}{l}\text { Nyaberaet al. } \\
(2020)\end{array}$ & USA & 290 & $77.6 \pm 8.3$ & 150 (51.7) & $\begin{array}{l}\text { Single-center } \\
\text { retrospective } \\
\text { cohort study }\end{array}$ & CAD & $\begin{array}{l}80 \\
(27.6)\end{array}$ \\
\hline $\begin{array}{l}\text { Ozturk et al. } \\
(2021)\end{array}$ & Turkey & 1160 & $60.5(47-71)$ & $627(54.1)$ & $\begin{array}{l}\text { Multicenter, } \\
\text { retrospective, } \\
\text { observational } \\
\text { study }\end{array}$ & CVD & NR (NR) \\
\hline
\end{tabular}

$\begin{array}{llllll}\text { Druyan et al. } & \text { Israel } & 181 & 62.71^{*} & 107 \rrbracket 59.1 \rrbracket & \begin{array}{l}\text { Single center } \\ \text { study }\end{array} \\ (2021) & & & & \text { Heart failure } & \begin{array}{l}10 \\ (5.52)\end{array}\end{array}$

\begin{tabular}{|c|c|c|c|c|c|c|c|}
\hline $\begin{array}{l}\text { Alguwaihes et al. } \\
\text { (2020) }\end{array}$ & Saudi Arabia & 439 & $55(19-101)$ & $300(68.3)$ & $\begin{array}{l}\text { Single-center } \\
\text { retrospective } \\
\text { study }\end{array}$ & CVD & $\begin{array}{l}44 \\
(10.0)\end{array}$ \\
\hline
\end{tabular}

\begin{tabular}{|c|c|c|c|c|c|c|c|}
\hline $\begin{array}{l}\text { Özdemir et al. } \\
(2021)\end{array}$ & Turkey & 101 & $49.60 \pm 18$ & $55(54.4)$ & $\begin{array}{l}\text { Retrospective } \\
\text { study }\end{array}$ & $\begin{array}{l}\text { Chronic heart } \\
\text { failure }\end{array}$ & $10(9.9)$ \\
\hline $\begin{array}{l}\text { Gue et al. } \\
(2020)\end{array}$ & UK & 316 & $73.42 \pm 15.97$ & $192(61.1)$ & $\begin{array}{l}\text { Single-center } \\
\text { retrospective } \\
\text { cohort }\end{array}$ & CAD & $\begin{array}{l}48 \\
(15.19)\end{array}$ \\
\hline $\begin{array}{l}\text { Galiero et al. } \\
(2020)\end{array}$ & Italy & 618 & $65 \pm 15.2$ & 379 (61.3) & $\begin{array}{l}\text { Multicenter } \\
\text { retrospective } \\
\text { observational } \\
\text { cohort study }\end{array}$ & $\begin{array}{l}\text { Chronic Cardiac } \\
\text { Disease }\end{array}$ & $\begin{array}{l}166 \\
(26.9)\end{array}$ \\
\hline $\begin{array}{l}\text { Rosenthal et al. } \\
(2020)\end{array}$ & USA & 64781 & $56.1 \pm 19.9$ & $\begin{array}{l}31968 \\
(49.3)\end{array}$ & $\begin{array}{l}\text { Retrospective } \\
\text { cohort study }\end{array}$ & $\begin{array}{l}\text { Myocardial } \\
\text { infarction }\end{array}$ & $\begin{array}{l}3717 \\
(5.7)\end{array}$ \\
\hline
\end{tabular}

\begin{tabular}{|c|c|c|c|c|c|c|}
\hline $\begin{array}{l}\text { the World } \\
\text { Health } \\
\text { Organization }\end{array}$ & 44672 & $71^{*}$ & $\begin{array}{l}22981 \\
\square 51.44 \bigotimes\end{array}$ & NR & CVD & $\begin{array}{l}92 \\
(15.9)\end{array}$ \\
\hline
\end{tabular}


Multiple-case, multiple-center

Heart failure

30

(6.94)

\begin{tabular}{|c|c|c|c|c|c|c|c|}
\hline $\begin{array}{l}\text { Zhou et al. } \\
(2020)\end{array}$ & China & 134 & $62.08 \pm 14.38^{*}$ & 85 (63.4) & Retrospective & $\begin{array}{l}\text { Coronary heart } \\
\text { disease }\end{array}$ & $\begin{array}{l}16 \\
(11.94)\end{array}$ \\
\hline $\begin{array}{l}\text { Stefan et al. } \\
(2021)\end{array}$ & Romania & 37 & $64(55-71)$ & $19(51)$ & $\begin{array}{l}\text { Retrospective, } \\
\text { observational, } \\
\text { single-center } \\
\text { study }\end{array}$ & $\begin{array}{l}\text { Coronary heart } \\
\text { disease }\end{array}$ & $\begin{array}{l}19 \\
(51.0)\end{array}$ \\
\hline
\end{tabular}

\begin{tabular}{|c|c|c|c|c|c|c|c|}
\hline $\begin{array}{l}\text { Ahnach et al. } \\
\text { (2021) }\end{array}$ & Morocco & 101 & $50(32-63)$ & 75 (51.72) & $\begin{array}{l}\text { Retrospective } \\
\text { study }\end{array}$ & CVD & $\begin{array}{l}16 \\
(11.03)\end{array}$ \\
\hline $\begin{array}{l}\text { Eshrati et al. } \\
(2020)\end{array}$ & Iran & 3188 & $55.05 \pm 0.31$ & $1925(60.4)$ & $\begin{array}{l}\text { Retrospective } \\
\text { cohort study }\end{array}$ & CVD & $\begin{array}{l}401 \\
(12.6)\end{array}$ \\
\hline
\end{tabular}

\begin{tabular}{|c|c|c|c|c|c|c|c|}
\hline $\begin{array}{l}\text { Özyılmaz et al. } \\
(2020)\end{array}$ & Turkey & 105 & $45(20-87)$ & $76(72.3)$ & $\begin{array}{l}\text { Single-center, } \\
\text { retrospective, } \\
\text { observational } \\
\text { study }\end{array}$ & CAD & $\begin{array}{l}14 \\
(13.3)\end{array}$ \\
\hline $\begin{array}{l}\text { Tan et al. } \\
(2020)\end{array}$ & China & 163 & $\begin{array}{l}69.0(62.0- \\
78.0)\end{array}$ & 109 (66.9) & $\begin{array}{l}\text { Retrospective } \\
\text { study }\end{array}$ & $\begin{array}{l}\text { Chronic cardiac } \\
\text { injury }\end{array}$ & $\begin{array}{l}25 \\
(15.3)\end{array}$ \\
\hline $\begin{array}{l}\text { Ling et al. } \\
(2020)\end{array}$ & UK & 444 & $74(63-83)$ & 245 (55.2) & $\begin{array}{l}\text { Cross- } \\
\text { Sectional } \\
\text { Multi-Centre } \\
\text { Observational } \\
\text { Study }\end{array}$ & Heart failure & $\begin{array}{l}54 \\
(12.2)\end{array}$ \\
\hline
\end{tabular}

\begin{tabular}{|c|c|c|c|c|c|c|c|}
\hline $\begin{array}{l}\text { Zhong et al. } \\
(2020)\end{array}$ & China & 126 & $66.3 \pm 10.6$ & $56(44.4)$ & $\begin{array}{l}\text { Retrospective } \\
\text { observational } \\
\text { study }\end{array}$ & CVA & $\begin{array}{l}21 \\
(16.7)\end{array}$ \\
\hline $\begin{array}{l}\text { Izurieta et al. } \\
(2020)\end{array}$ & USA & 12613 & $80.5^{\star}$ & $6496(51.5 \rrbracket$ & $\begin{array}{l}\text { Retrospective } \\
\text { cohort study }\end{array}$ & $\begin{array}{l}\text { Congestive Heart } \\
\text { Failure }\end{array}$ & $\begin{array}{l}3557 \\
(28.2)\end{array}$ \\
\hline
\end{tabular}




\begin{tabular}{|c|c|c|c|c|c|c|c|}
\hline $\begin{array}{l}\text { Burrell et al. } \\
(2021)\end{array}$ & Australia & 304 & $63.5(53-72)$ & $140(69 \%)$ & $\begin{array}{l}\text { Prospective, } \\
\text { observational } \\
\text { cohort study }\end{array}$ & $\begin{array}{l}\text { Chronic cardiac } \\
\text { disease }\end{array}$ & $40(20)$ \\
\hline $\begin{array}{l}\text { Li et al. } \\
(2020)\end{array}$ & China & 123 & $64.43 \pm 14.02$ & $62(50.41)$ & $\begin{array}{l}\text { Retrospective } \\
\text { study }\end{array}$ & CVD & $\begin{array}{l}26 \\
(21.14)\end{array}$ \\
\hline $\begin{array}{l}\text { Caliskan et al. } \\
(2020)\end{array}$ & Turkey & 56 & $48 \pm 19.664$ & NR & $\begin{array}{l}\text { Retrospective } \\
\text { observational } \\
\text { study }\end{array}$ & CAD & $42(7.4)$ \\
\hline $\begin{array}{l}\text { Vafadar et al. } \\
\text { (2021) }\end{array}$ & Iran & 219 & $57.8 \pm 16.5$ & $137(62.6)$ & $\begin{array}{l}\text { Retrospective } \\
\text { cohort }\end{array}$ & $\begin{array}{l}\text { Ischemic heart } \\
\text { disease }\end{array}$ & $\begin{array}{l}46 \\
(22.37)\end{array}$ \\
\hline $\begin{array}{l}\text { Working group for the surveillance and } \\
\text { control of COVID-19 in Spain et al. } \\
(2020)\end{array}$ & Spain & 2612 & $83(75-89)$ & $\begin{array}{l}14680 \\
(56.2)\end{array}$ & NR & CVD & $\begin{array}{l}11444 \\
(59.9)\end{array}$ \\
\hline $\begin{array}{l}\text { Rashidi et al. } \\
\text { (2021) }\end{array}$ & $\begin{array}{l}\text { Iran, } \\
\text { Germany, } \\
\text { USA }\end{array}$ & 1529 & $56(32-80)$ & $832(54.4)$ & $\begin{array}{l}\text { Multi-center } \\
\text { prospective } \\
\text { study }\end{array}$ & Cardiac disease & $\begin{array}{l}149 \\
(9.7)\end{array}$ \\
\hline $\begin{array}{l}\text { Chaudhri et al. } \\
(2020)\end{array}$ & USA & 317 & $59.16 \pm 17.5$ & $166(52.37)$ & $\begin{array}{l}\text { Single-center } \\
\text { cohort study }\end{array}$ & $\begin{array}{l}\text { Coronary artery } \\
\text { disease }\end{array}$ & $27(12)$ \\
\hline $\begin{array}{l}\text { Huh et al. } \\
\text { (2021) }\end{array}$ & South Korea & 219961 & $\begin{array}{l}49.4(18- \\
116)\end{array}$ & $\begin{array}{l}104331 \\
(47.4)\end{array}$ & $\begin{array}{l}\text { Retrospective } \\
\text { case-control } \\
\text { study }\end{array}$ & $\begin{array}{l}\text { Chronic heart } \\
\text { disease }\end{array}$ & $\begin{array}{l}32457 \\
(14.76)\end{array}$ \\
\hline
\end{tabular}

\begin{tabular}{|c|c|c|c|c|c|c|c|}
\hline $\begin{array}{l}\text { Orioli et al. } \\
(2021)\end{array}$ & Belgium & 73 & $69 \pm 14$ & $48(66.67)$ & $\begin{array}{l}\text { Retrospective } \\
\text { study }\end{array}$ & CVD & $\begin{array}{l}32 \\
(43.8)\end{array}$ \\
\hline Gude-Sampedro et al. (2021) & Spain & 10454 & $58.0 \pm 20.0$ & 4172 (39.9) & $\begin{array}{l}\text { Retrospective } \\
\text { cohort study }\end{array}$ & $\begin{array}{l}\text { Ischemic heart } \\
\text { disease }\end{array}$ & \\
\hline $\begin{array}{l}\text { Monteiro et al. } \\
(2020)\end{array}$ & USA & 112 & $61(45-74)$ & $74(66)$ & $\begin{array}{l}\text { Retrospective, } \\
\text { observational } \\
\text { cohort study }\end{array}$ & CAD & $17(15)$ \\
\hline $\begin{array}{l}\text { Lano et al. } \\
(2020)\end{array}$ & France & 122 & $\begin{array}{l}73.5(64.2- \\
81.2)\end{array}$ & $79(65)$ & $\begin{array}{l}\text { Observational } \\
\text { cohort } \\
\text { multicenter } \\
\text { study }\end{array}$ & $\begin{array}{l}\text { Congestive heart } \\
\text { failure }\end{array}$ & $13(11)$ \\
\hline $\begin{array}{l}\text { Lanini et al. } \\
(2020)\end{array}$ & Italy & 379 & $61.67 \pm 15.60$ & $273(72.03)$ & $\begin{array}{l}\text { Longitudinal } \\
\text { cohort study }\end{array}$ & CVD & $\begin{array}{l}19 \\
(5.01)\end{array}$ \\
\hline $\begin{array}{l}\text { Schwartz et al. } \\
(2020)\end{array}$ & Canada & 56606 & $31 *$ & $\begin{array}{l}29205 \\
(51.59)\end{array}$ & $\begin{array}{l}\text { Cross- } \\
\text { sectional study }\end{array}$ & CVD & $\begin{array}{l}4465 \\
(7.89)\end{array}$ \\
\hline
\end{tabular}




$\begin{array}{llllll}\text { Sun et al. } & \text { China } & 3400 & 61(50-68) & 1649(48.5) & \begin{array}{l}\text { Retrospective } \\ \text { cohort study }\end{array} \\ (2021) & & & & \text { CVD } & \begin{array}{l}343 \\ (10.1)\end{array}\end{array}$

\begin{tabular}{|c|c|c|c|c|c|c|c|}
\hline McGurnaghan et al. (2021) & Scotland & 319349 & $\begin{array}{l}79.9(71.4- \\
85.7)\end{array}$ & $\begin{array}{l}180486 \\
(56.5)\end{array}$ & Cohort study & Any heart disease & $\begin{array}{l}696 \\
(64.3)\end{array}$ \\
\hline
\end{tabular}

\begin{tabular}{|c|c|c|c|c|c|c|c|}
\hline $\begin{array}{l}\text { Cetinkal et al. } \\
(2020)\end{array}$ & Turkey & 349 & $68.3 \pm 13.3$ & $176(50.43)$ & $\begin{array}{l}\text { Retrospective } \\
\text { single-center } \\
\text { study }\end{array}$ & Heart failure & $\begin{array}{l}38 \\
(10.89)\end{array}$ \\
\hline $\begin{array}{l}\text { Xu et al. } \\
(2020)\end{array}$ & China & 61 & $63.62 \pm 10.78$ & $33(54.1)$ & Retrospective & Heart diseases & $7(11.5)$ \\
\hline $\begin{array}{l}\text { Lv et al. } \\
\text { (2021) }\end{array}$ & China & 409 & $50.47 \pm 12.43$ & $188(46)$ & $\begin{array}{l}\text { Retrospective } \\
\text { cohort Study }\end{array}$ & Heart disease & $\begin{array}{l}51 \\
(12.5)\end{array}$ \\
\hline
\end{tabular}

\begin{tabular}{|c|c|c|c|c|c|c|}
\hline $\begin{array}{l}\text { Guerra et al. } \\
\text { (2021) }\end{array}$ & Spain & 447 & $55.0 \pm 22.5$ & $190(46.4)$ & $\begin{array}{l}\text { Retrospective } \\
\text { single center } \\
\text { study }\end{array}$ & $\begin{array}{l}\text { Coronary artery } \\
\text { disease }\end{array}$ \\
\hline
\end{tabular}

*, studies included 2 two different cohort samples; HTN, Hypertension; SOFA, sequential organ failure assessment; ALT, alanine aminotransferase; AST, aspartate aminotransferase; ARDS, acute respiratory distress syndrome; INR, international normalized ratio; ICU, intensive care unit; HF, heart failure; IL-8, interleukin-8; AKI, acute cardiac injury; CLD, chronic lung diseases; CRD, chronic renal disease; CKD, chronic kidney disease; IL-6, interleukin-6; WBC, white blood cell; NR, not reported; HTN, hypertension; HR, hazard ratio; OR, odds ratio; Cl: confidence interval; CHD, coronary heart disease; CVD, cardiovascular disease; CAD, coronary artery disease; CKD, chronic kidney diseases; CLD, chronic liver diseases; COPD, chronic obstructive pulmonary disease; CRP, C-reactive protein; hs-CRP, high-sensitivity C-reactive protein; BMI, body mass index; LYM\%, lymphocyte percentage; NEU\%, neutrophil percentage; NLR, ratio of neutrophil to lymphocyte; FIB, fibrinogen content; TBIL, total bilirubin; ALB, albumin; $\mathrm{Cr}$, creatinine; GFR, glomerular filtration rate; CK-MB, creatine kinase isoenzyme-MB; CT, computerized tomography; PCT, procalcitonin; GGO, ground-glass opacity; ICl, immune check point inhibitors; HCQ, hydroxychloroquine; AZM, azithromycin; APTT, activated partial thromboplastin time; ACE, angiotensin converting enzyme inhibitors; ARB, angiotensin II receptor blockers; eGFR, estimated glomerular 
filtration rate; $\mathrm{PAD}$, peripheral arterial disease; $\mathrm{Hb}$, hemoglobin; $\mathrm{LDH}$, lactate dehydrogenase; ESR, erythrocyte sedimentation rate; MYO, myoglobin; LFTs, liver function tests; SABA, short acting beta agonists; ESRD, end-stage renal disease (on dialysis); ALC, absolute lymphocyte count; ANC, absolute neutrophil count; MV, mechanical ventilation; APACHE II, acute physiology and chronic health evaluation II; BUN, blood urea nitrogen; CVA ,cerebrovascular accident; TIA transient ischemic attack; DBIL, direct bilirubin; IBIL, indirect bilirubin; PT, prothrombin time; FBG, fasting blood glucose.

Table 2: Subgroup analysis 


\begin{tabular}{|c|c|c|c|c|c|}
\hline \multirow[t]{2}{*}{ Variables } & \multirow[t]{2}{*}{ Effects } & \multirow[t]{2}{*}{ NO. Of studies } & \multicolumn{2}{|l|}{ Subgroup analysis } & \multirow[t]{2}{*}{ Prediction interval } \\
\hline & & & Pooled ES (95\% Cl) & $I^{2} \otimes T a u^{2}, P$ value & \\
\hline \multicolumn{6}{|l|}{ Sample size } \\
\hline \multirow[t]{2}{*}{$>=1000$} & $\mathrm{HR}$ & 24 & $1.16(1.03-1.32)$ & $I^{2}=88 \%, \tau^{2}=0.0697 \otimes P<0.01$ & $0.66-2.04$ \\
\hline & OR & 53 & $1.41(1.32-1.51)$ & $I^{2}=84 \%, \tau^{2}=0.0694 \llbracket P<0.01$ & $0.84-2.39$ \\
\hline \multirow[t]{2}{*}{$<1000$} & $\mathrm{HR}$ & 41 & $1.63(1.41-1.88)$ & $I^{2}=64 \%, \tau^{2}=0.0957 \otimes P<0.01$ & $0.86-3.10$ \\
\hline & OR & 83 & $1.57(1.40-1.77)$ & $I^{2}=57 \%, \tau^{2}=0.0967 \otimes P<0.01$ & $0.84-2.95$ \\
\hline \multicolumn{6}{|l|}{ Age } \\
\hline \multirow[t]{2}{*}{$>=60$} & $\mathrm{HR}$ & 41 & $1.42(1.25-1.61)$ & $I^{2}=73 \%, \tau^{2}=0.0914 \rrbracket P<0.01$ & $0.76-2.65$ \\
\hline & OR & 78 & $1.49(1.34-1.65)$ & 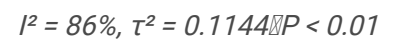 & $0.75-2.95$ \\
\hline \multirow[t]{2}{*}{$<60$} & $\mathrm{HR}$ & 23 & $1.18(1.04-1.33)$ & $I^{2}=81 \%, \tau^{2}=0.0181 \otimes P<0.01$ & $0.77-1.80$ \\
\hline & OR & 58 & $1.30(1.19-1.42)$ & $I^{2}=76 \%, \tau^{2}=0.0379 \llbracket P<0.01$ & $0.87-1.94$ \\
\hline \multirow[b]{2}{*}{ NR } & $\mathrm{HR}$ & 1 & $2.59(1.16-5.79)$ & - & - \\
\hline & OR & 2 & $1.75(0.67-4.61)$ & $I^{2}=88 \%, \tau^{2}=0.4301 \rrbracket P<0.01$ & - \\
\hline \multicolumn{6}{|l|}{ Male (\%) } \\
\hline \multirow[t]{2}{*}{$>=50$} & HR & 44 & $1.41(1.23-1.60)$ & $I^{2}=83 \%, \tau^{2}=0.1123 \llbracket P<0.01$ & $0.71-2.80$ \\
\hline & OR & 94 & $1.33(1.23-1.44)$ & $I^{2}=78 \%, \tau^{2}=0.0558 \otimes P<0.01$ & $0.83-2.14$ \\
\hline \multirow[t]{2}{*}{$<50$} & $\mathrm{HR}$ & 21 & $1.25(1.13-1.38)$ & $I^{2}=55 \%, \tau^{2}=0.0179 \llbracket P<0.01$ & $0.92-1.69$ \\
\hline & OR & 36 & $1.42(1.27-1.58)$ & $I^{2}=56 \%, T^{2}=0.0431 \llbracket P<0.01$ & $0.92-2.20$ \\
\hline \multirow[t]{2}{*}{ NA } & $\mathrm{HR}$ & 0 & - & - & - \\
\hline & OR & 8 & $2.25(0.87-5.79)$ & $I^{2}=98 \%, \tau^{2}=1.6735 \square P<0.01$ & $0.08-65.97$ \\
\hline \multicolumn{6}{|l|}{ Study design } \\
\hline \multirow[t]{2}{*}{ Retrospective/case series } & $\mathrm{HR}$ & 38 & $1.50(1.30-1.73)$ & $I^{2}=81 \%, \tau^{2}=0.1067 \otimes P<0.01$ & $0.76-2.96$ \\
\hline & OR & 88 & $1.37(1.28-1.47)$ & $I^{2}=65 \%, \tau^{2}=0.0269 \llbracket P<0.01$ & $0.98-1.91$ \\
\hline \multirow[t]{2}{*}{ Prospective study } & $\mathrm{HR}$ & 9 & $1.11(0.74-1.67)$ & $I^{2}=88 \%, \tau^{2}=0.2724 \llbracket P<0.01$ & $0.28-4.39$ \\
\hline & OR & 7 & $1.31(0.84-2.06)$ & $I^{2}=77 \%, \tau^{2}=0.2451 \llbracket P<0.01$ & $0.32-5.34$ \\
\hline \multirow[t]{2}{*}{ Others } & $\mathrm{HR}$ & 19 & $1.25(1.12-1.39)$ & $I^{2}=63 \%, \tau^{2}=0.0214 \llbracket P<0.01$ & $0.90-1.74$ \\
\hline & OR & 43 & $1.45(1.24-1.70)$ & $I^{2}=93 \%, \tau^{2}=0.1725 \llbracket P<0.01$ & $0.62-3.42$ \\
\hline \multicolumn{6}{|l|}{ Region } \\
\hline \multirow[t]{2}{*}{ Europe } & HR & 27 & $1.31(1.17-1.47)$ & $I^{2}=83 \%, \tau^{2}=0.0462 \otimes P<0.01$ & $0.83-2.08$ \\
\hline & OR & 54 & $1.47(1.33-1.64)$ & $I^{2}=75 \%, \tau^{2}=0.0725 \llbracket P<0.01$ & $0.85-2.56$ \\
\hline \multirow[t]{2}{*}{ North America } & $\mathrm{HR}$ & 12 & $1.16(1.02-1.33)$ & $I^{2}=52 \%, \tau^{2}=0.0234 \rrbracket P=0.02$ & $0.80-1.69$ \\
\hline & OR & 42 & $1.18(1.08-1.29)$ & $I^{2}=77 \%, \tau^{2}=0.0333 \otimes P<0.01$ & $0.81-1.72$ \\
\hline \multirow[t]{2}{*}{ Asia } & $\mathrm{HR}$ & 24 & $1.64(1.24-2.16)$ & $I^{2}=81 \%, \tau^{2}=0.3015 \bigotimes P<0.01$ & $0.51-5.30$ \\
\hline & OR & 37 & $1.55(1.29-1.87)$ & $I^{2}=68 \%, \tau^{2}=0.1272 \otimes P<0.01$ & $0.73-3.29$ \\
\hline & $\mathrm{HR}$ & 2 & $2.12(0.89-5.01)$ & $I^{2}=59 \%, \tau^{2}=0.2289 \llbracket P=0.12$ & - \\
\hline Others & OR & 5 & $3.54(0.86-14.60)$ & $I^{2}=92 \%, T^{2}=2.2249 \otimes P<0.01$ & $0.02-691.66$ \\
\hline Disease & & & & & \\
\hline CVD & $\mathrm{HR}$ & 27 & $1.36(1.15-1.61)$ & $I^{2}=79 \%, \tau^{2}=0.1154 \llbracket P<0.01$ & $0.66-2.80$ \\
\hline & OR & 41 & $1.48(1.24-1.76)$ & $I^{2}=91 \%, \tau^{2}=0.1984 \square P<0.01$ & $0.59-3.70$ \\
\hline & $\mathrm{HR}$ & 25 & $1.40(1.17-1.69)$ & $I^{2}=77 \%, \tau^{2}=0.1141 \rrbracket P<0.01$ & $0.68-2.90$ \\
\hline Cardiac disease & OR & 38 & $1.43(1.25-1.64)$ & $I^{2}=84 \%, \tau^{2}=0.0762 \varangle P<0.01$ & $0.80-2.55$ \\
\hline & $\mathrm{HR}$ & 4 & $1.23(1.05-1.44)$ & $I^{2}=89 \%, \tau^{2}=0.0173 \otimes P<0.01$ & $0.63-2.39$ \\
\hline $\mathrm{HF}$ & OR & 31 & $1.46(1.31-1.62)$ & $I^{2}=59 \%, \tau^{2}=0.0290 \otimes P<0.01$ & $1.01-2.10$ \\
\hline
\end{tabular}




\begin{tabular}{|c|c|c|c|c|c|}
\hline & $\mathrm{HR}$ & 9 & $1.48(1.14-1.93)$ & $I^{2}=70 \%, \tau^{2}=0.0957 \rrbracket P<0.01$ & $0.67-3.29$ \\
\hline CAD & OR & 26 & $1.17(1.02-1.35)$ & $I^{2}=52 \%, \tau^{2}=0.0416 \bigotimes P<0.01$ & $0.75-1.83$ \\
\hline \multirow[t]{2}{*}{ Others } & $\mathrm{HR}$ & - & - & - & \\
\hline & OR & 2 & $1.63(1.05-2.53)$ & $I^{2}=33 \%, \tau^{2}=0.0585 \otimes P=0.22$ & - \\
\hline \multicolumn{6}{|l|}{ Outcomes } \\
\hline \multirow[t]{2}{*}{ Mortality } & $\mathrm{HR}$ & 55 & $1.39(1.27-1.53)$ & $I^{2}=76 \%, \tau^{2}=0.0597[\mathrm{P}<0.01$ & $0.85-2.30$ \\
\hline & OR & 98 & $1.44(1.32-1.56)$ & $I^{2}=84 \%, \tau^{2}=0.0840, P<0.01$ & $0.80-2.57$ \\
\hline \multirow[t]{2}{*}{ Severity } & $\mathrm{HR}$ & 7 & $1.06(0.70-1.60)$ & $I^{2}=88 \%, \tau^{2}=0.2418 \otimes P<0.01$ & $0.30-3.68$ \\
\hline & OR & 25 & $1.22(1.03-1.43)$ & $I^{2}=66 \%, \tau^{2}=0.0575 \otimes P<0.01$ & $0.72-2.06$ \\
\hline \multirow[t]{2}{*}{ Disease progression } & $\mathrm{HR}$ & 3 & $1.65(1.20-2.27)$ & $I^{2}=0 \%, \tau^{2}=0.000 \otimes P=0.56$ & $0.21-12.92$ \\
\hline & OR & 15 & $1.63(1.31-2.04)$ & $I^{2}=68 \%, \tau^{2}=0.0858 \otimes P<0.01$ & $0.84-2.39$ \\
\hline
\end{tabular}

Note: $\mathrm{ES}$, effect sizes; $\mathrm{Cl}$, confidence interval; $\mathrm{OR}$, odds ratio; $\mathrm{HR}$, hazards ratio.

Meta-regression 


\begin{tabular}{|c|c|c|c|c|c|c|}
\hline \multirow[t]{2}{*}{ Variables } & \multicolumn{3}{|l|}{$\mathrm{HR}$} & \multicolumn{3}{|l|}{ OR } \\
\hline & $\mathrm{Tau}^{2}$ & $t$-value & P-value & $\mathrm{Tau}^{2}$ & $t$-value & P-value \\
\hline Sample size & 0.0753 & -0.3248 & 0.0007 & 0.0931 & -0.1552 & 0.0449 \\
\hline \multicolumn{7}{|l|}{$>=1000$} \\
\hline \multicolumn{7}{|l|}{$<1000$} \\
\hline Age & 0.0552 & - & 0.1123 & 0.0746 & - & 0.3495 \\
\hline$>=60$ & & 0.1404 & 0.1206 & & 0.1006 & 0.1674 \\
\hline \multicolumn{7}{|l|}{$<60$} \\
\hline NR & & 0.7562 & 0.1143 & & 0.1713 & 0.5027 \\
\hline Male (\%) & 0.0734 & 0.0351 & 0.7253 & 0.0997 & - & 0.0086 \\
\hline$>=50$ & & & & & -0.0678 & 0.4355 \\
\hline \multicolumn{7}{|l|}{$<50$} \\
\hline NR & & & & & 0.4272 & 0.0119 \\
\hline Study design & 0.0774 & - & 0.0828 & 0.0796 & - & 0.8863 \\
\hline Retrospective/case series & & 0.1064 & 0.3152 & & -0.0034 & 0.9647 \\
\hline Prospective study & & 0.1064 & 0.1628 & & -0.0823 & 0.6301 \\
\hline \multicolumn{7}{|l|}{ Others } \\
\hline Region & 0.0651 & - & 0.1800 & 0.0601 & - & $<0.0001$ \\
\hline Europe & & -0.1169 & 0.2910 & & -0.0307 & 0.7439 \\
\hline North America & & -0.2287 & 0.0746 & & -0.2362 & 0.0132 \\
\hline \multicolumn{7}{|l|}{ Asia } \\
\hline Others & & 0.3260 & 0.3447 & & 1.3471 & $<0.0001$ \\
\hline Disease & 0.0702 & - & 0.8655 & 0.1005 & - & 0.4005 \\
\hline CVD & & -0.1123 & 0.4286 & & 0.1737 & 0.1365 \\
\hline Cardiac disease & & -0.0681 & 0.6418 & & 0.1620 & 0.1741 \\
\hline $\mathrm{HF}$ & & -0.1221 & 0.5212 & & 0.2230 & 0.0640 \\
\hline \multicolumn{7}{|l|}{ CAD } \\
\hline Others & & & & & 0.82 & 0.413 \\
\hline Outcomes & 0.0694 & - & 0.0375 & 0.0810 & - & 0.1400 \\
\hline Mortality & & -0.0990 & 0.6880 & & -0.1298 & 0.2733 \\
\hline Severity & & -0.4713 & 0.0915 & & -0.2786 & 0.0528 \\
\hline Disease progression & & & & & & \\
\hline
\end{tabular}

\section{Figures}




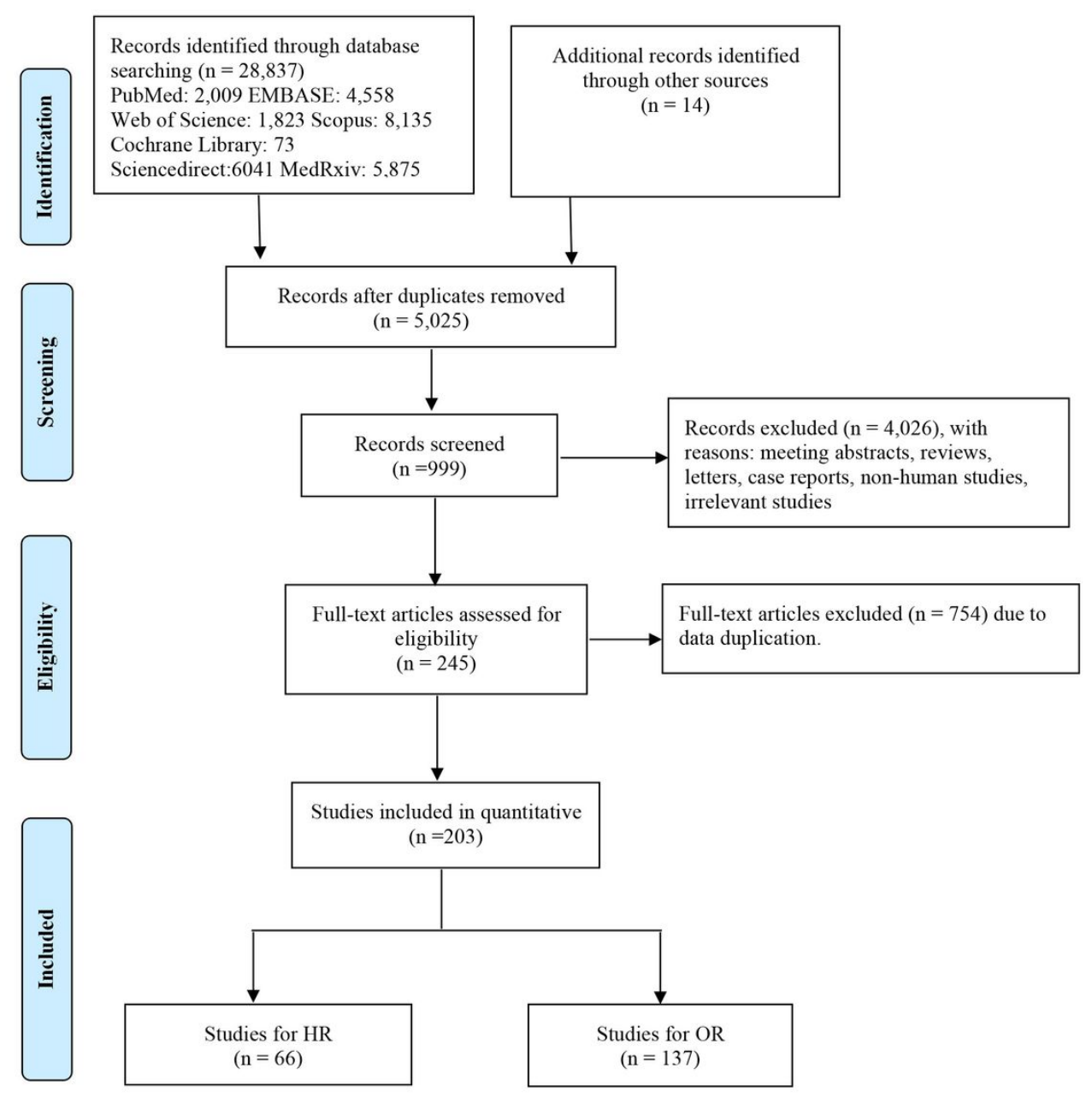

Figure 1

Flow diagram of selection process. 
A

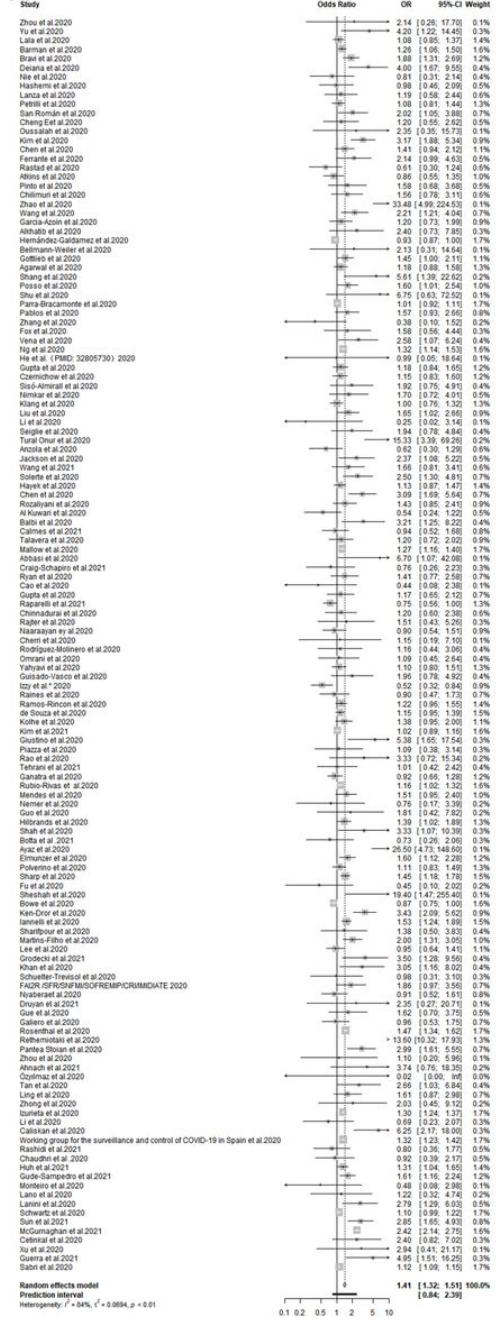

B

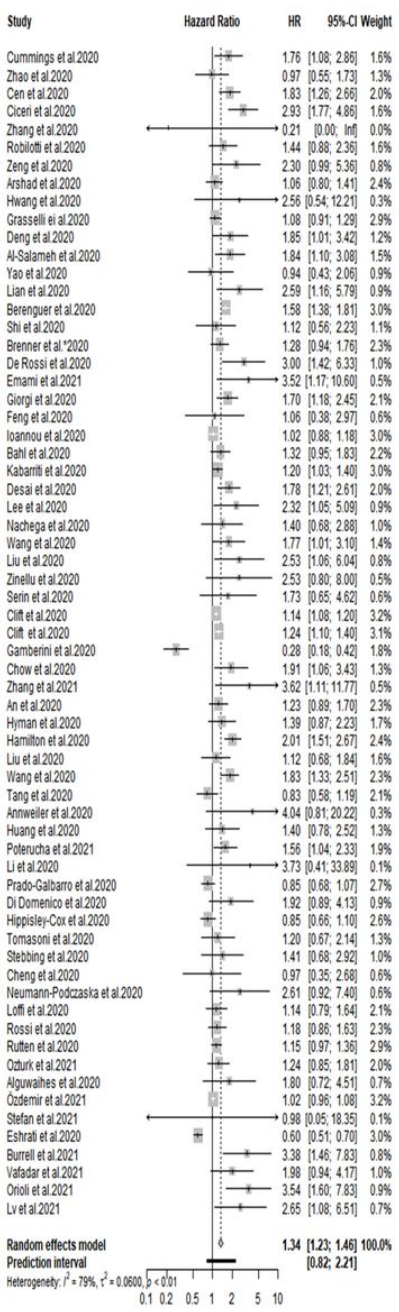

\section{Figure 2}

Forest plot of adjusted pooled effects for adverse outcomes associated with CVD in patients with COVID-19. A) Pooled OR; B) Pooled HR. 
A

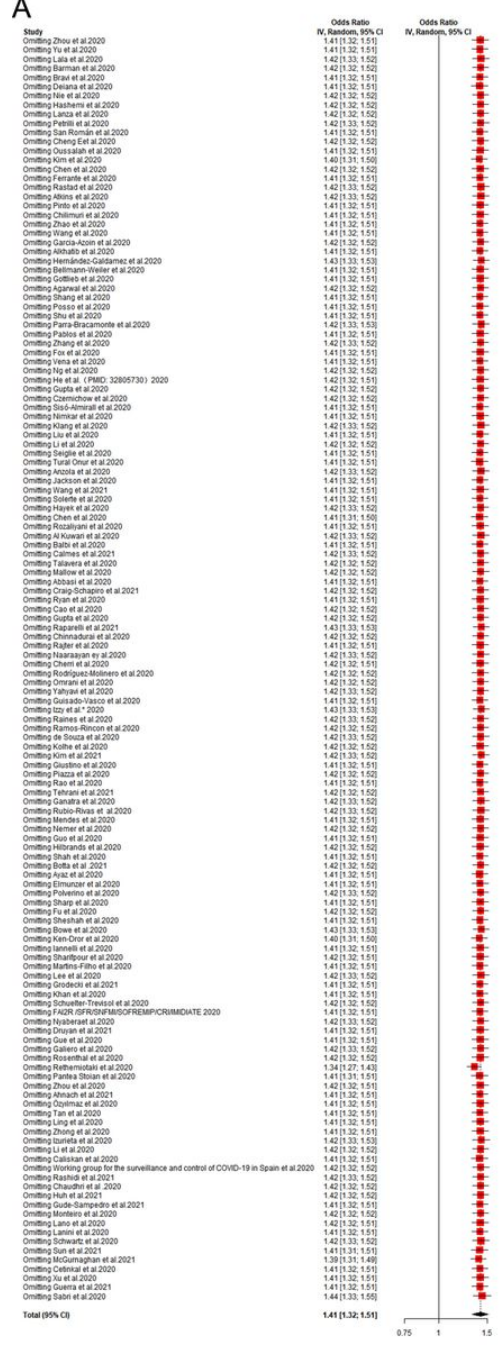

B

Ontrong Cummings tala 2020 Omitng grano etati 2020 Omitng Cene et al 22020 Omiting Gicentet al 202020

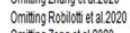

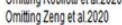
Omiting hishas tela 2 2020

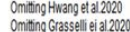

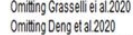
Ontang bengetalaver

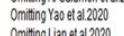
Omting Berenyue tat 2022 Imting Shit tat 2020 Omting B Benerest tal 20202 Ominno De Rossietala 20202 Omitnge Enami tata 2022 Omting Fengetal 2020 Omingnglagannou ét 12022 Omtinng Ban etat 2020 anteng kabaratit teat 202 Omting Dessa itat 20202 Ominto mathome Ontinng Lueta 12020 Onting Znellue ta 1.202 Omting Sern etal.2020

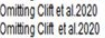

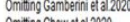
Onting Znangetala2021 Ontiting he tela 2020

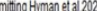
Omänng Hamitun efta 2020 Omitng Lue tat 20220 Omting Wangetal:2020

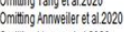
Ominong Huanget a 20202 Omitnon P Pleverch a tat 12021 intonglitat al22020

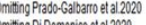
and

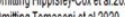

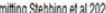
Dmiting Cheng gt a 2020

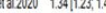

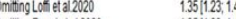

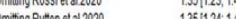

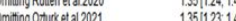

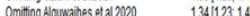

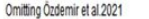
Omenongsetentala 2021

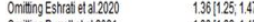

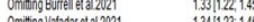

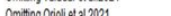

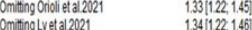

Total(955)(C)

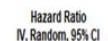

$134[122,14$
$1.351124,147$

13331122.195]

$134,123,14$

1341123,1

1.35124 .1469

1.35124 .1468

1341221.140

$1341122,146]$
1.3511231477

13311221465

13511123.147
134123147

1.331222 .165

13331122.1465
1341122165

1.4.1,

$1351124: 14$
1341123.14

1.351123 .14

$1.34122,146$

${ }_{134112314}^{124123,4}$

13411221.145
1341123

1.341123, 14

$1.35[123,1,168$

1371126.149

(4ine

1351123140
134112319

$133[122.145$

$1331122,1.55$

$1351124: 14$

14411231

1341123,14

$1341123: 14$
13561124.14

341123,140

$[124.46$

123,146

$23,146]$

23, 1.48$]$

$23,1.14]$

$[122,1.45]$

1.:4[1.23; 146]

0.75

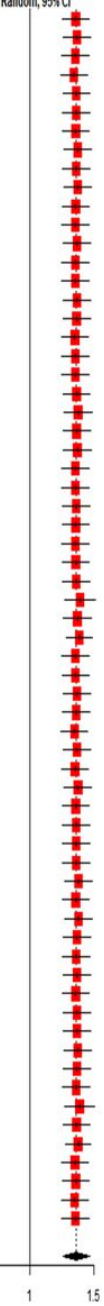

Figure 3

Sensitivity analysis for pooled OR (A) and HR (B). 
A

Begg's funnel plot with pseudo $95 \%$ confidence limits

10

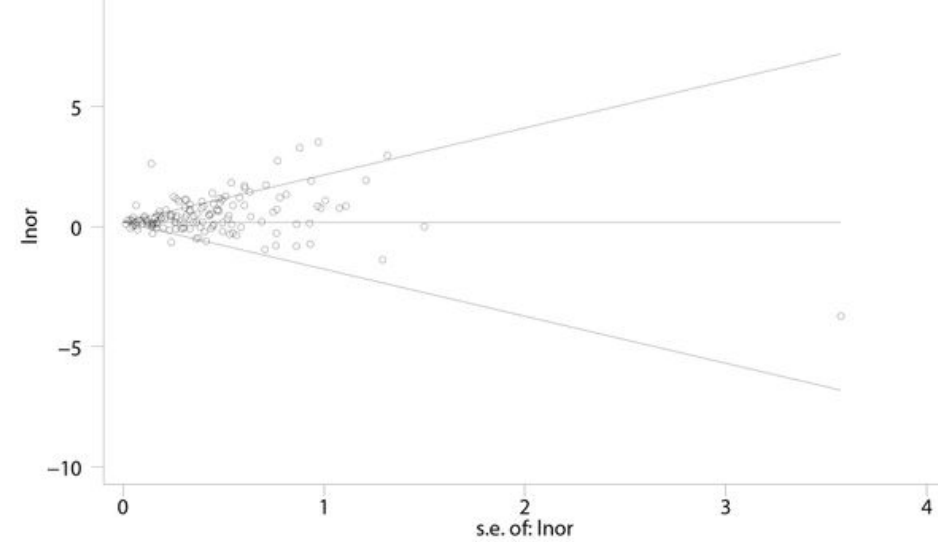

C Egger's publication bias plot

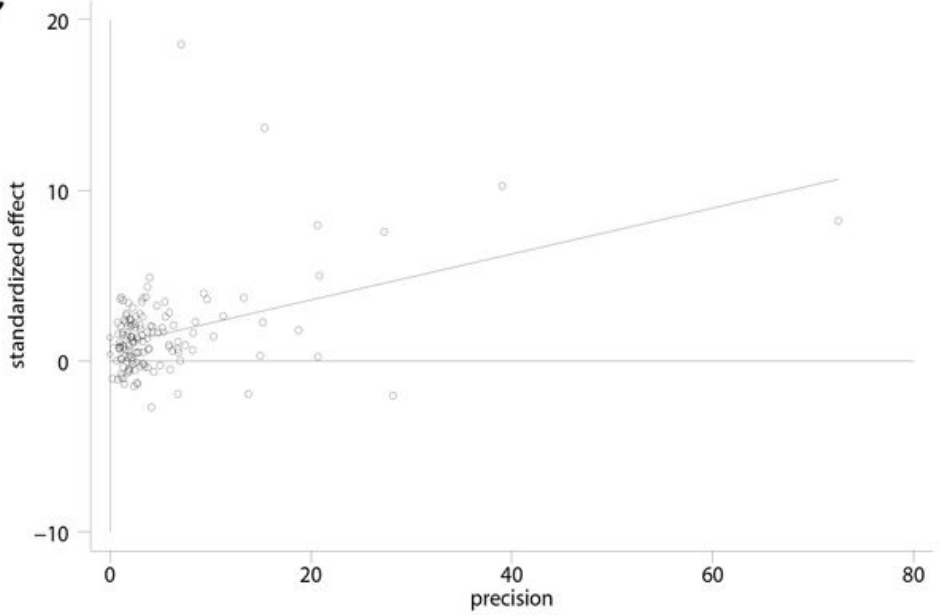

B

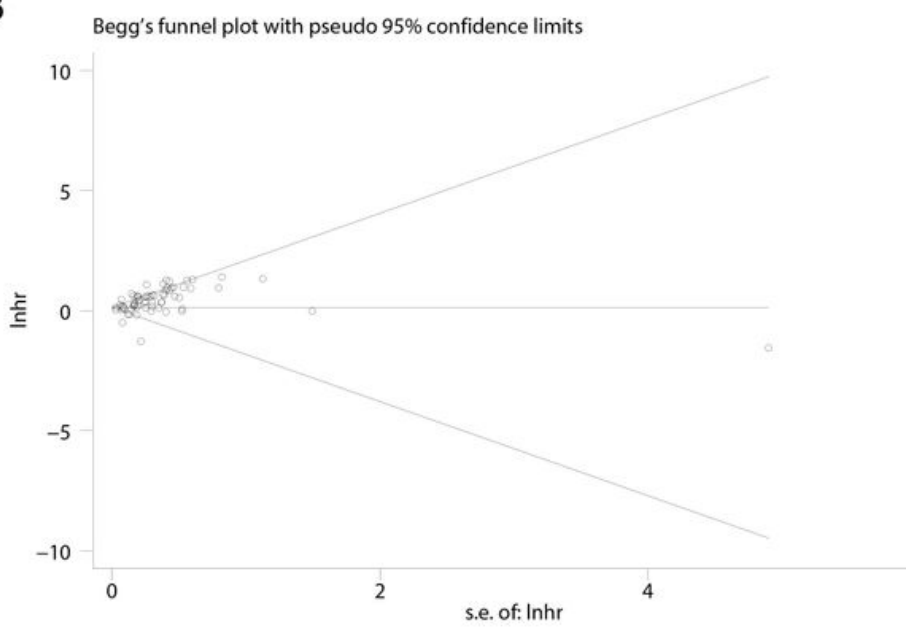

D

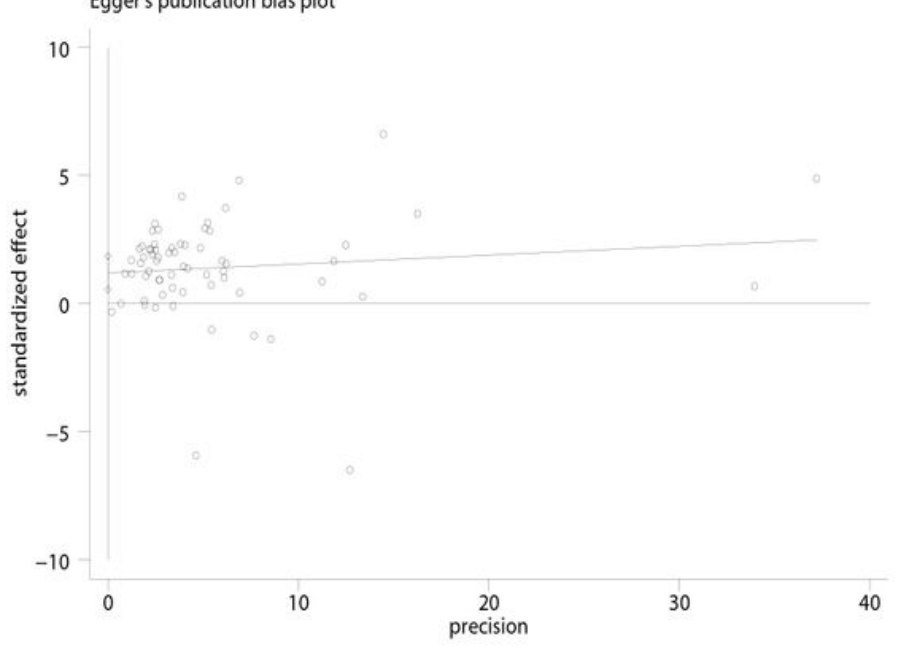

Figure 4

Publication bias for pooled OR (A and B) and HR (C and D)

\section{Supplementary Files}

This is a list of supplementary files associated with this preprint. Click to download.

- Additionalfile1.pdf 